\title{
EFFECTIVENESS OF DENITRIFYING BIOREACTORS ON WATER POLLUTANT REDUCTION FROM AGRICULTURAL AREAS
}

\author{
L. E. Christianson, R. A. Cooke, C. H. Hay, M. J. Helmers, G. W. Feyereisen, \\ A. Z. Ranaivoson, J. T. McMaine, R. McDaniel, T. R. Rosen, W. T. Pluer, \\ L. A. Schipper, H. Dougherty, R. J. Robinson, I. A. Layden, S. M. Irvine-Brown, \\ F. Manca, K. Dhaese, V. Nelissen, M. von Ahnen
}

\section{HighLIGHTS}

- Denitrifying woodchip bioreactors treat nitrate-N in a variety of applications and geographies.

- This review focuses on subsurface drainage bioreactors and bed-style designs (including in-ditch).

- Monitoring and reporting recommendations are provided to advance bioreactor science and engineering.

ABSTRACT. Denitrifying bioreactors enhance the natural process of denitrification in a practical way to treat nitrate-nitrogen $(N)$ in a variety of $N$-laden water matrices. The design and construction of bioreactors for treatment of subsurface drainage in the U.S. is guided by USDA-NRCS Conservation Practice Standard 605. This review consolidates the state of the science for denitrifying bioreactors using case studies from across the globe with an emphasis on full-size bioreactor nitrate- $N$ removal and cost-effectiveness. The focus is on bed-style bioreactors (including in-ditch modifications), although there is mention of denitrifying walls, which broaden the applicability of bioreactor technology in some areas. Subsurface drainage denitrifying bioreactors have been assessed as removing $20 \%$ to $40 \%$ of annual nitrate- $N$ loss in the Midwest, and an evaluation across the peer-reviewed literature published over the past three years showed that bioreactors around the world have been generally consistent with that (N load reduction median: 46\%; mean $\pm S D$ : $40 \%$ $\pm 26 \% ; n=15)$. Reported $N$ removal rates were on the order of $5.1 \mathrm{~g} \mathrm{~N} \mathrm{~m}^{-3} \mathrm{~d}^{-1}$ (median; mean $\pm S D: 7.2 \pm 9.6 \mathrm{~g} \mathrm{~N} \mathrm{~m}^{-3} \mathrm{~d}^{-1}$; $n=27)$. Subsurface drainage bioreactor installation costs have ranged from less than $\$ 5,000$ to $\$ 27,000$, with estimated cost efficiencies ranging from less than $\$ 2.50 \mathrm{~kg}^{-1} \mathrm{~N}$ year ${ }^{-1}$ to roughly $\$ 20 \mathrm{~kg}^{-1} \mathrm{~N}$ year ${ }^{-1}$ (although they can be as high as $\$ 48 \mathrm{~kg}^{-1} \mathrm{~N}$ year $\mathrm{r}^{-1}$ ). A suggested monitoring setup is described primarily for the context of conservation practitioners and watershed groups for assessing annual nitrate$N$ load removal performance of subsurface drainage denitrifying bioreactors. Recommended minimum reporting measures for assessing and comparing annual $N$ removal performance include: bioreactor dimensions and installation date; fill media size, porosity, and type; nitrate- $N$ concentrations and water temperatures; bioreactor flow treatment details; basic drainage system and bioreactor design characteristics; and $N$ removal rate and efficiency.

Keywords. Groundwater, Nitrate, Nonpoint-source pollution, Subsurface drainage, Tile.

Fabio Manca, Doctoral Student, Institute for Future Environments, Queensland University of Technology, Brisbane, Queensland, Australia; Kris Dhaese, Researcher, and Victoria Nelissen, Researcher, Research Center for Fruit (pcfruit npo), Sint-Truiden, Belgium; Mathis von Ahnen, Assistant Professor, Section for Aquaculture, Technical University of Denmark, North Sea Research Center, Hirtshals, Denmark. Corresponding author: Laura Christianson, AW-101 Turner Hall, 1102 South Goodwin Ave., University of Illinois, Urbana, IL 61801; phone: 217-244-6173; email: lechris@illinois.edu. 
$\mathrm{T}$ his article is part of a collection that provides a comprehensive review and evaluation of the performance and cost-effectiveness of selected agricultural conservation practices on nutrient and sediment reduction. The focus of this article is on denitrifying bioreactors for treatment of nitrate- $\mathrm{N}$ from agricultural water discharge.

The term denitrifying bioreactor most generally refers to a trench filled with carbonaceous media through which nitrate-laden water is routed (Christianson et al., 2012a; Schipper et al., 2010a). Wood is most commonly used as the carbon source inside these bioreactors. Denitrifying bacteria are fueled by the wood-sourced carbon to convert the nitrate-N in the water to dinitrogen gas. In more scientific terms, the woodchips supply dissolved organic carbon (DOC) to serve as the terminal electron acceptor in the dissimilatory stepwise reduction of nitrate- $\mathrm{N}$ to dinitrogen performed by chemo-heterotrophic denitrifying bacteria under anoxic conditions. This enhancement of the biological process of denitrification lends the name bio-reactor.

Schipper et al. (2010a) proposed definitions of three types of denitrifying bioreactors (beds, walls, and layers) to distinguish between designs based on their hydrological connections. Bed designs have generally been the most common, with recent interest leading to in-ditch variations (figs. 1a and $1 \mathrm{~b}$ ). The second most common type, denitrifying bioreactor walls, require less complicated design and construction (fig. 1c). Denitrifying layers are not discussed here.

Denitrification beds are woodchip-filled pits or trenches below the soil surface that receive water through a pipe either connected to a subsurface tile drain or a wastewater outlet (fig. 1a). Beds are the most common type of woodchip bioreactor in the U.S., and their design and construction for the treatment of nitrate in subsurface drainage water is guided by USDA-NRCS Conservation Practice Standard 605: Denitrifying Bioreactor (USDA, 2015). Subsurface drainage flow is driven by the head gradient created across the bioreactor following principles of flow through porous media; pumps are typically not used for this application (e.g., Christianson et al., 2012b; Rosen and Christianson, 2017; Woli et al., 2010). Internal plumbing manifolds and control

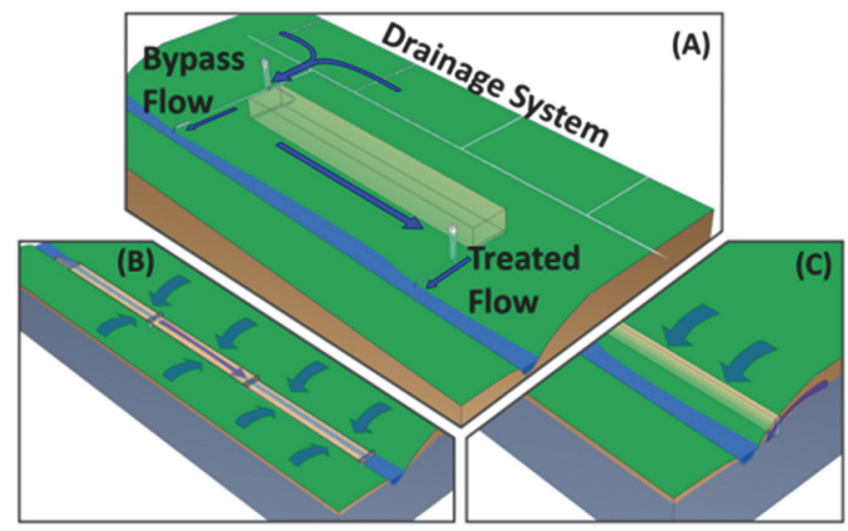

Figure 1. Three types of wood-based denitrifying bioreactors discussed in this article: (a) bed-style with internal plumbing, (b) in-ditch beds with protective gravel or mesh, and (c) wood-based denitrifying wall installed parallel to stream or ditch. structures route and control the saturated depth and flow. Top-down and other flow configurations have been used in other bed designs (e.g., Bruun et al., 2016; Schipper et al., 2010b; von Ahnen et al., 2018).

The NRCS Conservation Practice Standard recommends a design hydraulic retention time of $3 \mathrm{~h}$ at a design flow rate that is at least $15 \%$ of the peak estimated flow rate from the drainage system (USDA, 2015). While this $15 \%$ criterion is the most commonly used, designers can also choose to design a bioreactor based on treating the peak flow from a 10year, 24-hour drain flow event or treating at least $60 \%$ of the long-term average annual flow from the drainage system (USDA, 2015). Development of this Conservation Practice Standard in the early 2010 s lent important credibility to the practice of denitrifying bioreactors and critically allowed federal incentive payments to assist with bioreactor construction. The standard was based on the few published fieldscale studies available at the time, but because practice standards undergo periodic review and revision, future considerations should include refining the standard (e.g., Should the standard be load reduction outcomes-based rather than capacity-based? Are there sufficient data to support a load reduction-based standard?) and streamlining the design process (e.g., Are standardized plug-and-play bioreactor designs possible?).

Retrofitting bed-style bioreactors to be situated in streams or drainage ditches is a practical idea that is supported by farmers to minimize the risk of land removed from production (fig. 1b). Consideration must be given to minimizing flow restriction with in-ditch bioreactors, as flow conveyance is the primary responsibility of a ditch network. These designs have included wooden berms, gravel, and/or wire or plastic mesh to create woodchip bags or mattresses (Chase et al., 2019; Christianson et al., 2017; Dhaese et al., 2019; Pfannerstill et al., 2016; Robertson and Merkley, 2009). Design of these in-ditch systems has borrowed from the NRCS Conservation Practice Standard, but these systems have unique design, construction, and maintenance concerns (e.g., bypass flow goes over the top of the bioreactor, sedimentation is a significant issue).

Denitrification walls are installed across the flow path of groundwater often parallel and adjacent to an affected stream or drainage ditch (fig. 1c; Schipper and Vojvodic-Vukovic, 1998; Schmidt and Clark, 2012). The wall can be constructed using $100 \%$ carbon material or as a mixture of carbon material and native soil. There is no lining, and where possible, installing the bottom of the porous wall into a soil layer of low permeability is recommended to minimize flow short-circuiting under the reactive barrier. A major distinction between denitrifying beds and walls is that flow rates through beds tend to be much greater than that of walls. It is worth noting that while the NRCS Conservation Practice Standard was written with denitrifying beds in mind, it applies to sites where there is a need to reduce the nitrate-N concentration in subsurface drainage flow and does not require a certain type of implementation.

The overall objective of this article is to consolidate the state of the science for full-size denitrifying bioreactors across the globe to supplement the existing reviews and 
syntheses on this topic (Addy et al., 2016; Christianson et al., 2012a; Schipper et al., 2010a). "Field-scale" and "fullsize" bioreactors were loosely defined as meeting most of these factors: a bioreactor that was built on an operational farm (including some research farms); a given bioreactor (or bioreactor system, i.e., paired bioreactors in parallel) that was sized to receive drainage from a given drainage main (or other outflow system, e.g., agricultural wastewater); a bioreactor with a drainage treatment area of greater than $2 \mathrm{ha}$; no on-site replication was possible given the magnitude of the treatment system. An additional distinction between "pilot-scale" and "field-scale" is that the former is generally mainly intended for comparative assessments between treatments, as compared to providing a direct assessment of bioreactor performance under realworld conditions at full scale. Bioreactors treating subsurface drainage are emphasized because this special collection focuses on NRCS Conservation Practice Standards, but a variety of designs, applications, and water chemistries are included to more comprehensively reflect the current state of knowledge.

\section{Performance Effectiveness SEDIMENT}

Denitrifying woodchip bioreactors are capable of removing sediment via the physical process of filtration, but this capability can eventually hinder $\mathrm{N}$ removal performance. There are little field-scale data on sediment removal, likely because one of the main applications of denitrifying bioreactors in the U.S. is subsurface drainage water, which tends to have low sediment and suspended solids. When woodchip bioreactors are paired downstream of wetlands or sedimentation basins, total suspended solids (TSS) removal is generally excellent across the entire system (i.e., $>90 \%$; Choudhury et al., 2016; Tanner et al., 2012). Christianson et al. (2016) achieved $>90 \%$ TSS removal from aquaculture wastewater in pilot-scale bioreactors operated for more than 250 days, and in a similar wastewater study, Lepine et al. (2020a) reported that TSS removal decreased from $>90 \%$ to at least $64 \%$ after 637 days of operation when a total of 26 $\mathrm{kg}$ of TSS had been loaded into each bioreactor. Choudhury et al. (2016) estimated that only $7 \%$ of the woodchip pore space had been filled by sediment after a settling basinwoodchip bioreactor treatment system had been operated for seven months for high TSS wash water $(5800 \pm 2700 \mathrm{mg}$ TSS L-1). Woodchip clogging and siltation will eventually reduce bioreactor performance via flow restriction and development of preferential flow paths (Christianson et al., 2020). Using a woodchip bioreactor for sediment removal will shorten the design life for denitrification purposes, but the extent and timeframe of this process will likely depend on factors including the water matrix, loading rates, and bioreactor media.

\section{NitRATE-Nitrogen}

This description of full-size bioreactor nitrate-N removal performance is organized as a series of case studies contributed by the wide geography of co-authors. A range of applications and designs is presented to highlight local contextual insights and practical on-site knowledge. However, these case studies do not serve as an exhaustive list of every full-size bioreactor across the globe. A number of additional studies (e.g., Canadian studies: Gottschall et al. (2016), Husk et al. (2017); Danish studies: Bruun et al. (2016); Swedish treatment of mine drainage: Nordström and Herbert, 2019) are mentioned in other sections per the focus of the given study.

In general, subsurface drainage denitrifying bioreactors remove $20 \%$ to $40 \%$ of the annual nitrate-N loss according to science reviews in Midwestern state nutrient strategies (IDALS, 2014; IDOA, 2015). This typically ranges from 0.5 to $20 \mathrm{~kg} \mathrm{~N} \mathrm{ha}^{-1}$ removed from fields with $\mathrm{N}$ losses of 1.0 to $>60 \mathrm{~kg} \mathrm{~N} \mathrm{ha}^{-1}$ (Christianson et al., 2012b; Woli et al., 2010). A 2016 meta-analysis showed that $\mathrm{N}$ removal rates most commonly range from 0.5 to $10 \mathrm{~g}$ of $\mathrm{N}$ removed per cubic meter of bioreactor per day $\left(\mathrm{g} \mathrm{N} \mathrm{m}^{-3} \mathrm{~d}^{-1}\right)$ for bed-style designs (Addy et al., 2016). A more recent compilation of studies is presented in table A1 in the Appendix, which shows that the majority of bioreactor beds in the most current pool of literature (since 2016) are treating inflow nitrate-N concentrations in the range of 5.20 to $9.75 \mathrm{mg} \mathrm{NO}_{3}-\mathrm{N} \mathrm{L}^{-1}$ (25th and 75 th percentiles; fig. 2a) with hydraulic retention times of generally less than $2 \mathrm{~d}$ (75th percentile: $44 \mathrm{~h}$; fig. $2 \mathrm{~b}$ ). Nitrogen load reductions across the most current literature (fig. 2c; median: $46 \%$; mean \pm SD: $40 \% \pm 26 \%$ ) were consistent with Midwestern state strategy documents, although these bioreactors were from a variety of locations worldwide and the inclusion of untreated bypass flow in these load reduction efficiencies was not reported consistently across the literature (i.e., a mix is represented here). Nitrogen removal rates aligned with the earlier meta-analysis by Addy et al. (2016) with a median of $5.1 \mathrm{~g} \mathrm{~N} \mathrm{~m}^{-3} \mathrm{~d}^{-1}$ (fig. $2 \mathrm{c}$; mean $\pm \mathrm{SD}$ : $\left.7.2 \pm 9.6 \mathrm{~g} \mathrm{~N} \mathrm{~m}^{-3} \mathrm{~d}^{-1}\right)$.

\section{SubSuRfaCe DRainage DENITRIFYING BIOREACTORS IN THE U.S. MIDWEST Illinois}

Some of the earliest documented subsurface drainage denitrifying bioreactor studies in the U.S. were performed in Illinois (Cooke et al., 2001). By 2019, Illinois had 37 fieldscale bioreactors treating approximately 1,345 drained acres, which was an increase from 20 reported bioreactors (611 treated acres) in 2017 (IDOA and IEPA, 2019). Many of these are research and demonstration sites and are not designed following the NRCS Conservation Practice Standard (USDA, 2015). The bioreactors currently being monitored that were designed to the NRCS standard have treated drainage areas of 2.8 to 20 ha and tend to be 9.8 to $23 \mathrm{~m}$ long and 1.8 to $5.8 \mathrm{~m}$ wide, with the depth set by the depth of the existing drainage system. Roughly seven site-years from four NRCS-designed bioreactors generally show that $15 \%$ to $98 \%$ of the water from the field has been treated $(2,900$ to $26,200 \mathrm{~m}^{3}$ treated annually) with $12 \%$ to $98 \%$ of the nitrate routed into the bioreactor removed (5.4 to $168 \mathrm{~kg} \mathrm{~N}$ removed annually; 0.8 to $8.3 \mathrm{~kg} \mathrm{~N}^{-1}$ removed annually; removal rates: 2.1 to $6.6 \mathrm{~g} \mathrm{~N} \mathrm{~m}^{-3} \mathrm{~d}^{-1}$ ). Nitrate-N loss reductions at the edge of the field considering the untreated bypass flow tend 

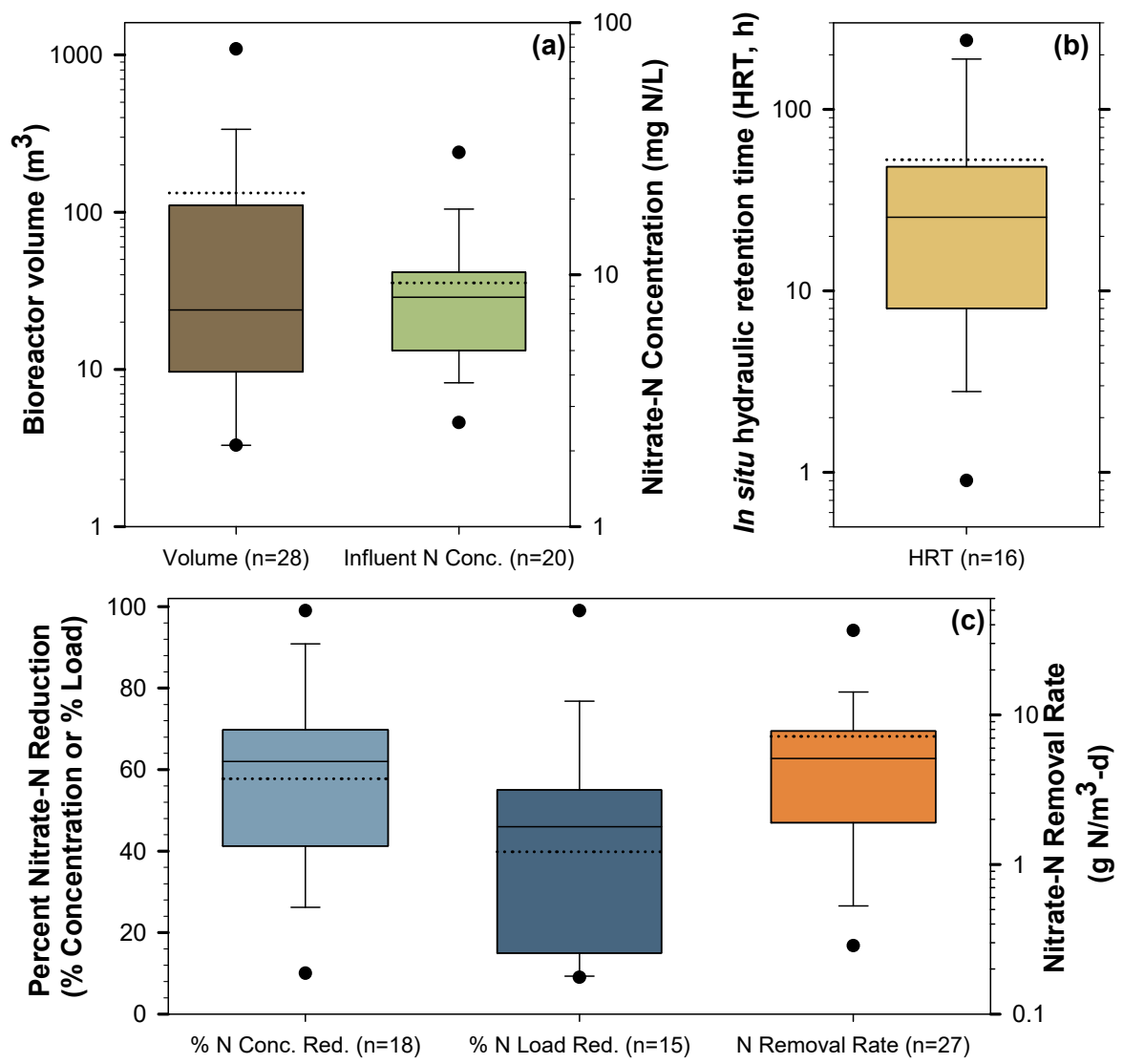

Figure 2. Survey of details compiled from full-size peer-reviewed bioreactor studies published since the meta-analysis by Addy et al. (2016). See table $\mathrm{A1}$ in the Appendix for data. Boxes, stems, and dots represent the 25th and 75th, 10th and 90th, and 5th and 95th percentiles, respectively; the solid line is the median, and the dotted line is the mean.

to be around $20 \%$ for these NRCS-designed bioreactors (L. Christianson, unpublished). The Illinois Nutrient Loss Reduction Strategy currently assesses bioreactors at a $25 \%$ edge-of-field $\mathrm{N}$ loss reduction (IDOA, 2015).

Full-size bioreactor research in Illinois currently focuses on refining design criteria and processes and advancing unique designs. A bioreactor designed with baffles to more efficiently route flow has produced edge-of-field $\mathrm{N}$ load reductions of $22 \%$ to $24 \%$ over three years by treating $40 \%$ to $43 \%$ of the total flow from the field $\left(0.71\right.$ to $1.3 \mathrm{~g} \mathrm{~N} \mathrm{~m}^{-3} \mathrm{~d}^{-1}$; 2.70 to $4.03 \mathrm{~kg} \mathrm{~N}^{-1} \mathrm{a}^{-1}$ removed annually; Christianson, unpublished; Dougherty, 2018). Pairing bioreactors: (1) to operate in parallel under high flow conditions, (2) to treat inditch drainage water and water that has been diverted out of the ditch, and (3) with phosphorus removal structures are being trialed. Across the state, some of the most significant observed challenges include side-wall slumping as the woodchips degrade and plugging of the inflow pipe, likely due to excessive microbial growth and/or siltation near the inlet (David et al., 2016). Side-wall slumping can be mitigated by refilling with woodchips (open-top bioreactors, at least), but consistent underlying causes of early woodchip subsidence have yet to be determined. Modeling efforts to better predict bioreactor performance, with the ultimate aim of improving design procedures, are also a major emphasis of the work in Illinois (Cooke and Bell, 2014; Jang et al., 2018).

\section{Iowa}

One of the first studies of multiple field-scale bioreactors monitored four bioreactors in Iowa (Christianson et al., 2012b). Over 14 site-years, annual nitrate removal rates ranged from 0.38 to $7.76 \mathrm{~g} \mathrm{~N} \mathrm{~m}^{-3} \mathrm{~d}^{-1}$. Nitrate load reductions ranged from $12 \%$ to $76 \%$ (mean $45 \%$ ) for flow through the bioreactor and $12 \%$ to $57 \%$ (mean $32 \%$ ) for total flow (including bypass flow), which translated to 0.5 to $15.5 \mathrm{~kg} \mathrm{~N} \mathrm{ha}^{-1}$ removed. Jones and Kult (2016) monitored five bioreactors in north central Iowa treating 10 to 20 ha of drainage area. All five bioreactors were designed to treat $20 \%$ of the estimated peak flow rate at a $4 \mathrm{~h}$ design hydraulic retention time. Average nitrate load reductions ranged from $50 \%$ to $80 \%$ for flow through the bioreactor, and for days when flow was measured, average nitrate removal rates ranged from 1.67 to $6.68 \mathrm{~g} \mathrm{~N} \mathrm{~m}^{-3}$. The science assessment in the Iowa Nutrient Reduction Strategy assigns an average nitrate load reduction of $43 \% \pm 21 \%$ (mean \pm SD) to bioreactors (IDALS, 2014), and there was a conservative estimate of 25 bioreactors in the state at the end of 2017 (IDALS, 2019).

The Greene County bioreactor, constructed in 2008 and monitored in both the Christianson et al. (2012b) and Jones and Kult (2016) studies, was recharged with new woodchips in 2017. A series of lab tests paired with field observations indicated that hydraulic changes from sedimentation and woodchip degradation created potential flow restrictions and preferential pathways. This, along with 
degradation in wood carbon content and quality, resulted in the need to recharge the bioreactor after nine years (Christianson et al., 2020).

\section{Minnesota}

Woodchip bioreactors were introduced in Minnesota in 2009. The first two monitored field-scale bioreactors were located at Dundas and Claremont, Minnesota, and were of a narrow, long design (Ranaivoson et al., 2012). Nitrate-N and total P load removal at the Dundas site $(27 \mathrm{~m} \mathrm{~L} \times 0.90 \mathrm{~m} \mathrm{~W}$ $\times 1.2 \mathrm{~m} \mathrm{D}$, woodchip depth) were $47 \%$ and $78 \%$, respectively, over a test period of three 6-day cycles at a $21 \mathrm{~h}$ hydraulic retention time (Ranaivoson et al., 2019). There are sporadic reports of unexpectedly early woodchip subsidence (e.g., within a few years of installation) at some Minnesota sites. Minnesota's northern climate creates cold weather challenges for bioreactor performance. Design and bioreactor fill modifications may be needed to improve performance under such conditions (Feyereisen et al., 2016). Current field research includes hydrologic and performance analysis of a unique multi-bed, cascading system at a community scale (250 ha watershed).

\section{South Dakota}

South Dakota State University has monitored four bioreactors as part of its ongoing research into management practices to reduce nutrient transport to surface waters. Two bioreactors were installed in 2012 (Baltic and Montrose, S.D.), one in 2013 (Arlington, S.D.), and one in 2014 (Hartford, S.D.) (Partheeban, 2014). These bioreactors were designed with hydraulic retention times ranging from 4.9 to $6.3 \mathrm{~h}$ at design flow rates that were $18 \%$ to $25 \%$ of the estimated peak flow rate from the drainage system. The dimensions of the first three bioreactors ranged from lengths of 35 to $40 \mathrm{~m}$ and widths of 3.7 to $6.4 \mathrm{~m}$ (Partheeban, 2014). Installation costs ranged from nearly $\$ 7,900$ to $\$ 10,400$. The bioreactors receive subsurface drainage from predominantly corn (Zea mays) and soybean (Glycine max) row crop systems, with the Hartford bioreactor inflow likely also receiving some manure influence from the nearby cattle confinement area.

During the monitoring periods (late spring to early fall), the bioreactors received flow for a majority of the time. Nine of the eleven site-years had flow into the bioreactor for over $71 \%$ of the monitoring period, with three site-years receiving flow for $100 \%$ of the monitoring period. Average flow rates were 5.6, 24.5, 9.7, and $0.62 \mathrm{~L} \mathrm{~s}^{-1}$ for the Montrose, Arlington, Baltic, and Hartford bioreactors, respectively, demonstrating a variety of flow regimes ( $\sim 0.7$ to 31 $\left.\mathrm{mm} \mathrm{d}^{-1}\right)$. The bioreactors generally removed the majority of the entering $\mathrm{N}$ load (i.e., $>50 \%$ concentration reductions). Mean nitrate concentration reductions for the individual sites were 54\% (Baltic, three years monitored, $\mathrm{n}=$ 41), 58\% (Montrose, three years monitored, $\mathrm{n}=39$ ), $60 \%$ (Hartford, two years monitored, $\mathrm{n}=19$ ), and 80\% (Arlington, three years monitored, $\mathrm{n}=39$ ), which were relatively consistent with figure $2 \mathrm{c}$.

\section{DRAINAGE DENITRIFYING BIOREACTORS \\ IN THE EASTERN U.S. \\ Maryland and the Delmarva Peninsula}

Ditches and tile drainage have benefitted production within this region's coastal plain but have also created an efficient pathway for nutrients to enter the Chesapeake Bay. There have been three field-scale tile drainage bioreactors monitored in Maryland and four field-scale ditch bioreactors monitored in Maryland and one in Delaware. Rosen and Christianson (2017) reported that the three tile drainage bioreactors were able to reduce nitrate-N loads by $9 \%$ to $62 \%$ and had an overall average load reduction efficiency of $24 \%$ (removal rates of 0.40 to $5.36 \mathrm{~g} \mathrm{~N} \mathrm{~m}^{-3} \mathrm{~d}^{-1}$ ). Beyond tile drainage, both bed-style and wall-style bioreactors have been adapted for the extensive ditch network found throughout Maryland and Delaware to improve the relevance of this practice to achieve Chesapeake Bay water quality goals. Three design modifications have been trialed: ditch-diversion bioreactors designed according to the NRCS Conservation Practice Standard, in-ditch bioreactors, and sawdust denitrification walls. The two ditch-diversion bioreactors have achieved $2 \%$ and $25 \% \mathrm{~N}$ load reduction efficiencies (Rosen, unpublished; Christianson et al., 2017). Load reduction efficiencies could not be calculated for the in-ditch bioreactors or sawdust denitrification walls due to difficulties in accurately assessing flow volumes; however, both designs achieved $\mathrm{N}$ concentration reductions $>65 \%$.

From a practical application perspective, the in-ditch bioreactor will need annual maintenance to reduce sedimentation. The sawdust wall, although inexpensive to install, will need hydrogeologic investigations to determine groundwater flow direction and to ensure that groundwater does not bypass under or around the wall. The ditch diversion bioreactor follows the NRCS standard, making design and implementation relatively straightforward, but, as with the wall, site selection is critical because ditch networks can intercept various sources and volumes of water that have variable concentrations of nitrate-N. The ditch-diversion bioreactor also proved relatively expensive to install $(>\$ 20,000)$. Bioreactor beds have recently been recommended to receive a $20 \%$ total nitrogen (TN) loss reduction credit in the Chesapeake Bay total maximum daily load (TMDL) model (Bryant et al., 2019).

\section{New York State}

Ten denitrifying bioreactors have been constructed on five farms throughout central and western New York for research and monitoring. These were generally located on dairy farms and treated effluent from tile-drained fields of 2 to $12 \mathrm{ha}$. The bioreactors were sized based on estimates of field drainage and a design hydraulic retention time of $20 \mathrm{~h}$ ( 6 to $9 \mathrm{~m} \mathrm{~L} \times 3$ to $4.5 \mathrm{~m} \mathrm{~W} \times 1$ to $1.5 \mathrm{~m} \mathrm{D}$ ). At some sites, paired bioreactors were used, with one of each pair amended with biochar (10:1 woodchip to biochar ratio by volume), although the impacts of these additions are dependent on the specific biochar's properties. The $\mathrm{N}$ removal rate across all bioreactors averaged approximately $5 \mathrm{~g} \mathrm{~N} \mathrm{~m}^{-3} \mathrm{~d}^{-1}$ (annual range: 3 to $15 \mathrm{~g} \mathrm{~N} \mathrm{~m}^{-3} \mathrm{~d}^{-1}$ ). Temperature had a significant effect on $\mathrm{N}$ removal rate, with temperatures below $5^{\circ} \mathrm{C}$ resulting in lower rates (Hassanpour et al., 2017). Low nitrate 
inflow concentration and low DOC in the effluent also resulted in limited removal rates, although only low DOC resulted in low removal efficiency. Both removal rate and efficiency dropped significantly after storm events; however, the highest instantaneous removal rates were measured during peak flows (Pluer et al., 2019).

\section{INTERNATIONAL BIOREACTOR APPLICATIONS New Zealand}

In New Zealand, the first denitrification wall (40 m long) was constructed in early 1996 to determine whether this approach could be used to remove nitrate from shallow groundwater of a grazed dairy farm. A series of studies demonstrated that nitrate removal exceeded 95\% (Schipper and Vojvodic-Vukovic, 1998), denitrification was the mechanism of removal (Schipper et al., 2005; Schipper and Vojvodic-Vukovic, 2000), and removal occurred for at least 15 years (Long et al., 2011). Nitrate-N removal rates $\left(\sim 1 \mathrm{~g} \mathrm{~N} \mathrm{~m}^{-}\right.$ ${ }^{3} \mathrm{~d}^{-1}$ ) were lower than reported for denitrification beds because there were lower carbon contents (roughly $5 \% \mathrm{C}$ by weight), as sawdust was mixed with soil on-site, and because nitrate inputs were low due to slow movement of groundwater (Addy et al., 2016). A second wall (120 m long) installed nearby into sandy soils experienced bypass flow due to a large reduction in hydraulic conductivity (Schipper et al., 2004) due to repacking of the sand (Barkle et al., 2008), demonstrating that care was needed with denitrifying wall installation in aquifers with high conductivity. From the mid-2000s, large denitrification beds (ranging from 40 to $150 \mathrm{~m} \mathrm{~L} \times 4$ to $7 \mathrm{~m} \mathrm{~W} \times$ generally $1.5 \mathrm{~m} \mathrm{D}$ ) were constructed for treatment of $\mathrm{N}$-laden water from subsurface drains, domestic wastes, dairy farm effluent, and hydroponic glasshouse runoff production. High rates of nitrate removal were demonstrated (e.g., 5 to $10 \mathrm{~g} \mathrm{~N} \mathrm{~m}^{-3} \mathrm{~d}^{-1}$; Schipper et al., 2010b; Warneke et al., 2011b) that were shown to be supported by denitrification (Warneke et al., 2011a).

\section{Southeast Queensland, Australia}

The Pumicestone Passage in southeast Queensland is a valuable ecological and recreational waterway located 70 $\mathrm{km}$ north of Brisbane between Bribie Island and the Australian mainland. Land use adjacent to catchment waterways is dominated by intensive horticulture comprised predominantly of strawberry, pineapple, and macadamia production. Annual water quality assessments for the Passage and its freshwater catchment have shown a decline since 2006, with significant loads of nitrate contributed by the agricultural area in the northern region of the catchment. Manca et al. (2020) described the design and performance of two denitrification walls $\left(20 \mathrm{~m} \mathrm{~L} \times 1.0 \mathrm{~m} \mathrm{~W} \times 1.4 \mathrm{~m} \mathrm{D} ; 27 \mathrm{~m}^{3}\right.$ each; 3 $\mathrm{m}$ apart) that were constructed in June 2017 and filled with either a softwood (Pinus caribaea) or hardwood mix (Eucalyptus spp.). Design parameters primarily accounted for depth to the aquitard, available land, surface drainage ditches, size of the excavator and attachments (i.e., the wall width was set to the width of the excavator bucket), required volume of woodchips, and sampling needs. The installation cost of the bioreactors was approximately $\$ 50 \mathrm{AUD} \mathrm{m}^{-3}$ (approx. \$35 USD $\mathrm{m}^{-3}$ ) including materials and excavation.
The denitrification walls removed all the nitrate- $\mathrm{N}$ transported in groundwater (inflow range 0.0 to $22.7 \mathrm{mg} \mathrm{NO}_{3}-\mathrm{N}$ $\mathrm{L}^{-1}$ ) based on weekly sampling over two years. Such high removal was facilitated by the development of anaerobic conditions (average $<1.1 \mathrm{mg} \mathrm{L}^{-1} \mathrm{DO}$ ) and high temperatures $\left(21^{\circ} \mathrm{C}\right.$ to $\left.27^{\circ} \mathrm{C}\right)$, with persistent nitrate limitation and higher methane production during transition to unsaturated conditions. The average removal rates for the softwood and hardwood walls were 2.0 and $1.6 \mathrm{~g} \mathrm{~N} \mathrm{~m}^{-3} \mathrm{~d}^{-1}$, respectively, consistent with previous denitrification walls (Fahrner, 2002; Jaynes et al., 2008; Robertson et al., 2000). Results were similar to values reported by Schipper et al. (2005) due to occurrence of nitrate limitation in the walls, and such limitations necessarily caused uncertainty in the quantification of maximum removal rates.

In 2015, the Australian and Queensland governments released the Great Barrier Reef 2050 Long-Term Sustainability Plan to provide an overarching framework for managing water quality in the Great Barrier Reef lagoon (Australia, 2018). Denitrifying bioreactors have been identified as a potential treatment option for reducing point-source and diffuse environmental nitrate loading from agriculture into the lagoon. Bioreactors are currently being trialed in a number of catchments throughout Queensland to test their $\mathrm{N}$ removal efficacy across differing climates, soil types, and agricultural production systems. As of November 2019, it is estimated that 30 comparably monitored bioreactors are operating in Australia, with more than 20 of the systems in northern Queensland in close proximity to the Great Barrier Reef (i.e., the Australian Bioreactor Network; ABC Rural News, 2020).

\section{Belgium}

A woodchip bioreactor $\left(65 \mathrm{~m} \mathrm{~L} \times 2 \mathrm{~m} \mathrm{~W} \times 1 \mathrm{~m} \mathrm{D} ; 127 \mathrm{~m}^{3}\right.$ of hardwood species) was installed in July 2018 in a ditch in Peer, Belgium (Flanders), that transports nitrate-rich drainage water from sandy fields. The relatively high nitrate concentrations (e.g., $>30 \mathrm{mg} \mathrm{NO} \mathrm{NO}_{3}-\mathrm{N} \mathrm{L}^{-1}$ ) cannot be linked directly to current in-field fertilizer management but are likely rather due to historic nitrate-rich groundwater reaching the surface. From June 2018 to July 2019, the mean bioreactor inflow and outflow $\mathrm{NO}_{3}-\mathrm{N}$ concentrations were 28.6 and $8.9 \mathrm{mg} \mathrm{NO}_{3}-\mathrm{N} \mathrm{L}^{-1}$, respectively (mean of 36 measurements), which corresponded to an average concentration reduction of $69 \%$. The maximum concentration reduction for a given sample event was $97 \%$. There was an anecdotal increase in $\mathrm{N}$ removal during higher temperatures, which has been well documented by others (Addy et al., 2016).

The oak (genus Quercus) wood used in the bioreactor leached high amounts of color (even blackish color) for several weeks after installation. Very low dissolved oxygen content was measured in the ditch for at least $9 \mathrm{~d}$ following installation. One and a half years after installing the bioreactor, an additional $15 \mathrm{~m}^{3}$ of woodchips was added to prevent too much bypass flow over the top of the in-ditch design.

As an EU member state, Flanders is held to a threshold value of $11.4 \mathrm{mg} \mathrm{NO}_{3}-\mathrm{N} \mathrm{L}^{-1}$ ( or $50 \mathrm{mg} \mathrm{NO}_{3}^{-} \mathrm{L}^{-1}$ ) in surface and groundwater (EU, 1991). Despite more than 20 years of work toward these goals, many monitoring locations in Flanders still exceed these values. In 2019, the Flemish 
Government imposed new measures to accelerate progress in areas where the water quality threshold value has not been achieved including: (1) reduction of fertilizer rates, (2) increase in cover crop area, and (3) liquid animal manure can only be transported to arable fields by a recognized contractor. From 2020 onward, equivalent measures that have been approved by a special commission can be used by farmers to replace these three measures, given that the $\mathrm{N}$ mitigation effectiveness of the equivalent measure has been proven. Denitrifying woodchip bioreactors could possibly be a useful end-of-pipe "equivalent measure" technique in catchments where high nitrate concentrations in surface water cannot be linked to current fertilization practices.

\section{Denmark}

In Denmark, full-scale woodchip bioreactors in the size range of 350 to $6,000 \mathrm{~m}^{3}$ have been installed to treat the effluents from commercial recirculating aquaculture systems (RAS) rearing rainbow trout (Oncorhynchus mykiss) in freshwater. Aquacultural effluents typically contain higher loads of particulate organic matter compared to subsurface agricultural drainage, which poses a higher risk for bioreactor clogging. To reduce the risk for bioreactor clogging and associated head loss, the woodchip bioreactors were built as vertical down-flow filters with depths of 1.0 to $1.5 \mathrm{~m}$ with several outlet drainage pipes in the bottom to facilitate even distribution of water within the bioreactors. The bioreactors were installed within constructed wetlands to reduce the incoming particulate load and dissolved oxygen into the woodchips and alleviate the environmental impact of leached nutrients and organic matter on receiving water bodies during bioreactor start-up. In a one-year monitoring study, three full-scale woodchip bioreactors, which were operated at empty bed contact times of 15 to $21 \mathrm{~h}$ (i.e., volume of the empty reactor divided by the flow rate; does not consider woodchip porosity), achieved average nitrate-N removal rates of 4.5 to $7.8 \mathrm{~g} \mathrm{~N} \mathrm{~m}^{-3} \mathrm{~d}^{-1}$ at average water temperatures of $10^{\circ} \mathrm{C}$ (von Ahnen et al., 2018). The monitoring study confirmed that woodchip bioreactors can be applied as a technologically simple, low-maintenance method to remove nitrogen from aquaculture effluents, where their operation benefits from stable flow rates and nitrate loads. The costs for installation of woodchip bioreactors at Danish recirculated trout farms were 400 to $500 \mathrm{DKK} \mathrm{m}^{-3}$ bioreactor volume ( $\$ 60$ to $\$ 75 \mathrm{USD} \mathrm{m}^{-3}$ ). The cost per $\mathrm{kg} \mathrm{N}$ removed for this relatively high-solids application will be highly dependent on the required frequency of woodchip replacement (Lepine et al., 2018). The oldest woodchip bioreactor at a Danish RAS farm has only been operating for 2.5 years (at the time of writing) and still removes nitrate without any indications that replacement of the woodchips is necessary.

\section{TOTAL Nitrogen}

Much of the total nitrogen (TN) load in subsurface drainage in the U.S., the current most common application for woodchip bioreactors, is comprised of nitrate-N. The recent expert panel recommendation for the Chesapeake Bay TMDL model credits denitrifying bioreactors designed to the NRCS standard with a $20 \%$ TN reduction credit based on this assumption (Bryant et al., 2019). However, this will be water matrix specific, as nitrogen speciation will vary in wastewater or subsurface drainage in other locations (e.g., Irish drainage waters can contain relatively more ammonium-N than nitrate-N; Clagnan et al., 2018).

\section{Dissolved and Total Phosphorus}

Phosphorus $(\mathrm{P})$ is a macronutrient required for plant growth, and thus woodchips contain and will leach dissolved $\mathrm{P}$. There are few full-scale studies documenting $\mathrm{P}$ dynamics in denitrifying woodchip bioreactors treating subsurface drainage water; the results show a mix of $P$ leaching and removal, although most generally document $\mathrm{P}$ leaching upon bioreactor start-up. Flushing of $\mathrm{P}$ beyond the first year was observed by David et al. (2016) at a bioreactor in Illinois $(15 \mathrm{~m} \mathrm{~L} \times 6.0 \mathrm{~m} \mathrm{~W} \times 1.3 \mathrm{~m} \mathrm{D} ; 20$ ha drainage area; installed 2012), where dissolved reactive phosphorus (DRP) loads entering and leaving the bioreactor were $0.1,1.0$, and $0.3 \mathrm{~kg}$ DRP versus $1.3,4.7$, and $1.0 \mathrm{~kg}$ DRP, respectively, across a three-year period (2012 to 2014). The two years in which total P (TP) was monitored showed a similar trend (inflow: 1.9 and $0.5 \mathrm{~kg}$ TP; outflow: 6.4 and $1.4 \mathrm{~kg} \mathrm{TP}$ ). Other bioreactors in Illinois have confirmed initial P flushing, with Bell et al. (2015) showing that outflow DRP concentrations can be an order of magnitude greater than the inflow within the first month of operation $\left(\sim 0.1\right.$ to 4.5 and $<0.1 \mathrm{mg} \mathrm{DRP} \mathrm{L}^{-1}$, respectively). Over the next six months of monitoring, the outflow concentrations were consistently elevated above the inflow, but these differences were not statistically significant. However, $\mathrm{P}$ removal in woodchip bioreactors is also possible, as Dougherty (2018) reported consistent $\mathrm{P}$ removal at a third bioreactor in Illinois $(16.8 \mathrm{~m} \mathrm{~L} \times 10.7 \mathrm{~m} \mathrm{~W} \times$ $0.91 \mathrm{~m} \mathrm{D} ; 14$ ha drainage area; installed 2016). The bioreactor removed $72 \%$ and $74 \%$ of the inflow dissolved $\mathrm{P}$ load in its first and second year, respectively, which equated to 0.01 and $0.08 \mathrm{~g} \mathrm{P}$ removed $\mathrm{m}^{-3} \mathrm{~d}^{-1}$ for the two periods. These trends of initial $\mathrm{P}$ flushing with the possibility of $\mathrm{P}$ removal generally hold across a variety of bioreactor applications, such as agricultural wash water (Choudhury et al., 2016), greenhouse effluent (Warneke et al., 2011b), and aquacultural wastewater (Sharrer et al., 2016: removal rates of 0.51 to $0.74 \mathrm{~g} \mathrm{TP} \mathrm{m}^{-3} \mathrm{~d}^{-1}$ and -0.74 to $0.23 \mathrm{~g} \mathrm{DRP} \mathrm{m}^{-3} \mathrm{~d}^{-1}$; von Ahnen et al., 2018: -0.2 to $0.1 \mathrm{~g} \mathrm{TP} \mathrm{m}^{-3} \mathrm{~d}^{-1}$ ).

Much work at the intersection of $\mathrm{P}$ and denitrifying woodchip bioreactors has been around the integration of P-sorbing media with the woodchips. Husk et al. (2018) compared a mixed-media bioreactor containing a gabion filled with activated alumina and gravel upstream of woodchips with three woodchip-only controls (range of 12 to $27 \mathrm{~m} \mathrm{~L} \times 0.9$ to 1.8 $\mathrm{m} \mathrm{W} \times 0.9 \mathrm{~m} \mathrm{D}$; drainage areas: 0.6 to $1.3 \mathrm{ha}$ ). They reported that all four bioreactors released $\mathrm{P}$ during the first year of operation, but overall, the bioreactor with the P-sorption media was more effective for $\mathrm{P}$ removal than the woodchiponly bioreactors, with removal rates of 0.36 and $0.02 \mathrm{~g}$ TP removed $\mathrm{m}^{-3} \mathrm{~d}^{-1}$, respectively. Neither the mixed-media bioreactor nor the woodchip-only bioreactors were able to treat the drainage water to below the threshold of $0.03 \mathrm{mg} \mathrm{TP} \mathrm{L}^{-1}$ for freshwater eutrophication. Nevertheless, this serves as one of the most current comprehensive studies of woodchip bioreactor $\mathrm{P}$ removal, particularly given the variety of $\mathrm{P}$ 
forms evaluated. The authors noted: "This three-year fieldscale study demonstrates that an agricultural subsurface drainage system with a woodchips-only bioreactor had lower $\mathrm{P}$ load in its outflow and a significant reduction in the bioavailable, soluble P fractions" (Husk et al., 2018).

There will be variability in the P-sorbing media used, as Bock et al. (2018) reported that the differences between inlet and outlet TP concentrations at a bioreactor $(5.8 \mathrm{~m} \mathrm{~L} \times$ $5.3 \mathrm{~m} \mathrm{~W} \times 0.8 \mathrm{~m} \mathrm{D}$; 6.5 ha drainage area) filled with volumetric ratio of $90 / 10$ woodchips/biochar were not significant (mean inflow and outflow: 0.13 and $0.03 \mathrm{mg} \mathrm{TP} \mathrm{L}^{-1}$, respectively). Several pilot-scale and lab-scale studies investigating the combination of woodchips and P-sorbing media have documented some dissolved $\mathrm{P}$ removal (generally $5 \%$ to $15 \%$ ) with woodchip-only treatments or column sections (Goodwin et al., 2015; Zoski et al., 2013; Li et al., 2018). Gottschall et al. (2016) reported that small replicated bioreactors $(2.4 \mathrm{~m} \mathrm{~L} \times 1.5 \mathrm{~m} \mathrm{~W} \times 0.9 \mathrm{~m} \mathrm{D})$ packed with only woodchips had TP and DRP removal efficiencies of $28 \%$ and $35 \%$, respectively. Bioreactors amended with alumbased drinking water treatment residuals provided more $\mathrm{P}$ removal (64\% TP and 89\% DRP; Gottschall et al., 2016). Hua et al. (2016) reported as much as $75 \%$ phosphate removal and removal rates as high as $0.88 \mathrm{~g} \mathrm{P} \mathrm{m}^{-3} \mathrm{~d}^{-1}$ by woodchips themselves in two phases of a small experiment pairing woodchips and steel slag.

In summary, there was variability in denitrifying bioreactor $\mathrm{P}$ leaching and removal across the literature. The mechanisms and consistency of this removal are unclear (Warneke et al., 2011b). The importance of P (and its variety of forms, e.g., Husk et al., 2018) for freshwater eutrophication make this an important area of continued research for woodchip bioreactors.

\section{Removal of Additional Pollutants}

The removal of pollutants beyond those mentioned above is a ripe topic for bioreactor research. Much early work in this area has necessarily been done at the lab scale (e.g., Ilhan et al. (2011) for atrazine, enrofloxacin, and sulfamethazine; Krause-Camilo et al. (2013) for atrazine; Zoski et al. (2013) for E. coli; Liu et al. (2014) for perchlorate; Bell (2019) for plant pathogens of the Phytophthora species), with a handful of field-scale studies reported here. For example, herbicide dissipation was evaluated at one of the Minnesota field-scale bioreactors described above (Dundas, Minn.). After three 6-day cycles at a $21 \mathrm{~h}$ hydraulic retention time, load reductions of acetochlor and atrazine were $70 \%$ and $53 \%$, respectively. However, adsorption was identified as the removal mechanism, and modeling indicated that herbicide breakthrough would occur within 18 days (Ranaivoson et al., 2019). Other recent work by Hassanpour et al. (2019) corroborated the ability of woodchip bioreactors to remove atrazine from drainage water in the field. Gottschall et al. (2016) reported that woodchip-only bioreactors receiving drainage from plots applied with liquid swine manure removed more than $70 \%$ of the tylosin, chlortetracycline, and isochlortetracycline in the water. They reiterated that the removal mechanism for veterinary antibiotic compounds appeared to be sorption; however, the ultimate fate of these chemicals is not known. Removal of microorganisms, including bacteria and viruses, has been documented with field-scale bioreactors (Rambags et al., 2016; Tanner et al., 2012). Most recently, mesocosm work by Rambags et al. (2019) demonstrated that ANAMMOX, in which ammonium oxidation is combined with nitrate reduction to produce the final product of nitrogen gas, was equally important as denitrification as a removal mechanism. The controls on this process were unclear, but it will only occur when sufficient dissolved ammonium and nitrate are present.

\section{LIMITATIONS AND TRADEOFFS}

No single conservation practice is a "silver bullet" for every situation or pollutant, and thus bioreactors have their limitations and tradeoffs, some of which were mentioned above. For example, practical maintenance considerations observed in the field include sporadic occurrences of woodchip slumping (in the Illinois and Minnesota sections above) and the need to remove sediment from in-ditch bioreactors (in the Maryland section above). Ditch-diversion bioreactors with a structure for water control to back up water within a ditch can also create stagnant water conditions, facilitating an anaerobic environment conducive to $P$ release (Sharpley et al., 2007). This is an important consideration for areas in Maryland and Delaware that have P-saturated soils. Such potential pollution swapping (i.e., release of one pollutant while trying to treat another) is an important consideration (Healy et al., 2012).

Many bioreactor pollution swapping studies have explored losses of dissolved organics and nutrients (e.g., DOC, chemical/biological oxygen demand, organic nitrogen, ammonium, phosphorus) at the bioreactor outlet, especially during bioreactor start-up, and emissions of greenhouse gases (nitrous oxide $\left(\mathrm{N}_{2} \mathrm{O}\right)$, methane, and carbon dioxide). Many small-scale bioreactor fill media comparisons have reported these start-up nutrient flushing issues (e.g., Gibert et al., 2008; Cameron and Schipper, 2010; Healy et al., 2012), and colored bioreactor outflow water has been observed during start-up at the field-scale (e.g., the Belgium section above). Additional woodchip leaching concerns, such as phenols and tannic acid, are starting to be investigated (Wickramarathne et al., 2020; Lepine et al., 2020b). These issues subside given sufficient flushing, which has ranged from 15 to roughly 300 cumulative pore volumes, or from a week to approximately six months, depending on the bioreactor size, fill media, and initial flow rate (Healy et al., 2012; Christianson et al., 2016; von Ahnen et al., 2016; Wickramarathne et al., 2020).

When considering greenhouse gas emissions, in addition to measuring the bioreactor emissions, it is critical to compare those measurements to the emissions that would have occurred in the absence of the bioreactor. For example, woodchips used for constructing a bioreactor would likely degrade with time in any case, so the carbon dioxide emissions from a bioreactor do not represent a net carbon dioxide contribution to the atmosphere. Similarly, in the absence of a bioreactor, a proportion of the leached nitrate could also be converted to $\mathrm{N}_{2} \mathrm{O}$ in receiving waters (e.g., Moorman et al., 
2010). In one of the first full-scale bioreactor studies to evaluate $\mathrm{N}_{2} \mathrm{O}$ losses, Elgood et al. (2010) reported that only $0.6 \%$ of the consumed $\mathrm{NO}_{3}-\mathrm{N}$ was released as $\mathrm{N}_{2} \mathrm{O}$ in an in-stream bioreactor. Goeller et al. (2019) recently reported that greenhouse gas fluxes from a subsurface drainage bed-style bioreactor in New Zealand were similar to emissions from the surrounding pasture, and Bock et al. (2018) reported that greenhouse gas emissions from a bioreactor in Virginia were similar to other nitrate treatment systems and were not "environmentally concerning." Similarly, Woli et al. (2010) reported that surface $\mathrm{N}_{2} \mathrm{O}$ fluxes at a bioreactor in Illinois were "of little concern." However, current work makes clear that dissolved gasses, in addition to surface fluxes, should be considered. Warneke et al. (2011b) and Bruun et al. (2017) both reported that the majority of $\mathrm{N}_{2} \mathrm{O}$ losses were in the dissolved form rather than emitted via the surface, although total $\mathrm{N}_{2} \mathrm{O}$ emissions were still only $4.3 \%$ and between $2.2 \%$ and $5.5 \%$, respectively, of removed nitrate. Bruun et al. (2017) and Elgood et al. (2010) both observed that bioreactors could, at times, be sinks for $\mathrm{N}_{2} \mathrm{O}$ from the atmosphere. However, methane emissions, which are another greenhouse gas consideration, have been observed under conditions leading to full consumption of nitrate, including low hydraulic loading and high temperatures (Elgood et al., 2010; Bruun et al., 2017).

Highly anaerobic conditions leading to methanogenesis can also be conducive to sulfate reduction. On one hand, sulfate reduction in bioreactors, which has been relatively widely documented (Warneke et al., 2011b; Shih et al., 2011; Christianson et al., 2012b; Corbett et al., 2020), could be considered treatment of an additional pollutant. On the other hand, sulfate reduction is associated with mercury methylation in natural systems. Mercury methylation in woodchip bioreactors can be avoided by maintaining bioreactor outflow nitrate concentrations of at least $0.5 \mathrm{mg}$ $\mathrm{NO}_{3}-\mathrm{N} \mathrm{L}^{-1}$ (Shih et al., 2011). Natarajan (2015) found no evidence of methylmercury generation when water with low nitrate-N concentrations was pumped into four field-scale bioreactors in Minnesota operating at hydraulic retention times $\geq 24 \mathrm{~h}$. Hudson and Cooke (2015) also measured the potential for methyl mercury production but in bioreactor designs in which the bioreactor bottom was $30 \mathrm{~cm}$ below the tile invert to provide longer residence times. They found negligible methyl mercury values during winter but high values during summer, particularly during times of low or no flow, likely due to highly reducing conditions in the stagnant pool of water below the tile invert. These findings led to new design recommendations in which the bottom of the bioreactor is at the same level as the tile invert. This recommendation was incorporated into the NRCS Conservation Practice Standard, which states: "If reducing conditions may result in the production of methyl mercury, make additional provisions to ensure that stagnant conditions do not develop in the media chamber" (USDA, 2015).

In terms of practice limitations, nitrate removal in bioreactors has been reported to be limited by cold climates, as noted in the Minnesota studies, or by low DOC during storm flows, as noted in the New York State section. Analysis of nitrate removal rates across regional or seasonal temperature gradients would provide added insight into bioreactor functioning and performance. Jang et al. (2018) and Nordström and Herbert (2019) described recent advances to bioreactor models to incorporate temperature sensitivity. Heating water to improve nitrate removal has been trialed with limited success (Rendall, 2015; Cameron and Schipper, 2011).

There are also monitoring limitations and challenges for quantifying the $\mathrm{N}$ removal performance of a variety of bioreactor designs (in the Maryland section above). For example, sawdust denitrifying walls may require hydrogeological investigations to determine $\mathrm{N}$ loading and treatment effectiveness. Christianson et al. (2017) suggested that it may be more practical to create groundwater flow rate estimates for regions within the Chesapeake Bay watershed, which could be used for denitrifying wall $\mathrm{N}$ loading estimates. Overall, more long-term studies, which face many challenges including funding cycles and limitations, staff turnover, and the need for long-term commitments by field site partners (e.g., landowners), are needed to advance bioreactor technologies.

\section{Cost-EFFEctiveness}

Christianson et al. (2012b) reported that installation costs for subsurface drainage bioreactors generally ranged from $\$ 6,940$ to $\$ 11,820$ in the relatively early days of field-scale bioreactor research in the Midwest. Scaled to drainage treatment area, these costs were $\$ 190 \mathrm{ha}^{-1}$ to $\$ 590 \mathrm{ha}^{-1}$, and for the one site where the volume was reported along with cost, the resulting cost efficiency was $\$ 77 \mathrm{~m}^{-3}$. In this review, bioreactor bed installation costs have ranged from $\$ 7,900$ to $\$ 10,400$ in South Dakota to more than $\$ 20,000$ in the Chesapeake Bay watershed. Work in the Chesapeake Bay illustrates that beds are more expensive than denitrifying walls (e.g., \$18,000 and $\$ 27,000$ vs. $<\$ 3,000$, respectively; Christianson et al., 2017), although the costs will be site and design specific. Schmidt and Clark (2012) reported a relatively early denitrifying wall cost of approximately $\$ 20,000$, which equated to $\$ 168 \mathrm{~m}^{-3}(55$ $\mathrm{m} \mathrm{L} \times 1.7 \mathrm{~m} \mathrm{~W} \times 1.8 \mathrm{~m} \mathrm{D}$ ). The Australian denitrifying walls described here were more cost-efficient at approximately $\$ 50$ AUD $m^{-3}$ (approx. \$35 USD m ${ }^{-3}$ ).

Initial evaluations of bioreactor $\mathrm{N}$ removal cost efficiency ranged from $\$ 2.40 \mathrm{~kg}^{-1} \mathrm{~N}$ to $\$ 15.20 \mathrm{~kg}^{-1} \mathrm{~N}$ (Schipper et al., 2010a; assumed 20-year life; 4\% annual interest), which have been corroborated with more recent estimations. For example, Sarris and Burbery (2018) assumed a 10-year life in a numerical simulation and determined that the average treatment cost would be $\$ 9.70 \pm \$ 3.10 \mathrm{NZD} \mathrm{kg}^{-1} \mathrm{~N}$ (mean \pm SD: $\$ 6.60 \pm \$ 2.10 \mathrm{USD} \mathrm{kg}^{-1} \mathrm{~N}$ ) for an in-stream bioreactor in New Zealand. Lepine et al. (2018) detailed the full itemization for initial bioreactor installation $\left(\$ 47,840 ; \$ 140 \mathrm{~m}^{-3}\right)$ and subsequent woodchip replacement $(\$ 19,470$ per replacement) assuming a variety of clogging scenarios with aquaculture wastewater. They estimated that bioreactors had conservative cost efficiencies of $\$ 5.50 \mathrm{~kg}^{-1} \mathrm{~N}$ to $\$ 13.40 \mathrm{~kg}^{-1} \mathrm{~N}$, with improved cost efficiencies occurring at reduced frequency of woodchip replacement (10-year planning horizon; $10.6 \%$ discount rate). Easton et al. (2019) reported cost efficiencies of $\$ 0.54$ to $\$ 7.60 \mathrm{~kg}^{-1} \mathrm{~N}$ year ${ }^{-1}$ for bioreactors treating legacy $\mathrm{N}$ in spring water, with an economy of scale noted 
for treatment of larger springs $\left(>500 \mathrm{~m}^{3} \mathrm{~d}^{-1}\right.$ flows $)$ and greater cost efficiency for springs with higher nitrate-N concentrations ( 7.3 versus $\left.3.8 \mathrm{mg} \mathrm{NO}-\mathrm{N} \mathrm{L}^{-1}\right)$. The bioreactor cost efficiencies reported by DeBoe et al. (2017) ranged higher, at $\$ 15 \mathrm{~kg}^{-1} \mathrm{~N}$ year ${ }^{-1}$ to $\$ 48 \mathrm{~kg}^{-1} \mathrm{~N}$ year-1, using a case study installation cost of $\$ 11,060\left(\$ 181 \mathrm{~m}^{-3}\right)$. This equated to a total annualized cost of $\$ 994$ year $^{-1}$, assuming a 15 -year planning horizon and 4\% interest rate. Importantly, DeBoe et al. (2017) concluded that while bioreactors are a cost-effective practice, adoption may be slow due to the relatively high upfront cost and low incentives. The NRCS Conservation Practice Standard establishes ten years as the practice life for denitrifying bioreactors treating subsurface drainage (USDA, 2015).

Christianson et al. (2013) developed cost efficiencies for seven subsurface drainage conservation practices and reported that the constructed practices of bioreactors and wetlands had competitive cost efficiencies of less than $\$ 3 \mathrm{~kg}^{-1} \mathrm{~N}$ year $^{-1}$. These calculations assumed very small design service costs of only $\$ 40 \mathrm{~h}^{-1}$ for two days of bioreactor design work. Where bioreactors require engineering plans signed and sealed by a professional engineer to receive public funding, design costs may add $50 \%$ to $100 \%$ of the installation cost (average design cost of $\$ 7,500$ ) for bioreactors designed by private design firms. Additionally, the small project size and distributed nature (both spatially and temporally) of typical subsurface drainage bioreactor projects limits the appeal for many engineering consultants to provide this service. Design services provided by the USDA-NRCS, while free to the farmer or landowner, still come with a transaction cost in terms of design times that can be lengthier due to agency staffing constraints and competing program priorities.

In summary, reported subsurface drainage bioreactor installation costs have been less than $\$ 5,000$ (e.g., if contractor and design fees are waived) to $\$ 27,000$, volumetric costs have ranged from $\$ 77 \mathrm{~m}^{-3}$ to nearly $\$ 200 \mathrm{~m}^{-3}$, and cost efficiencies have been estimated at less than $\$ 2.50 \mathrm{~kg}^{-1} \mathrm{~N}$ yearranging generally to about $\$ 20 \mathrm{~kg}^{-1} \mathrm{~N}$ year ${ }^{-1}$ (although they can be as high as $\$ 48 \mathrm{~kg}^{-1} \mathrm{~N}$ year ${ }^{-1}$ ). There are too few woodchip bioreactor data to estimate sediment or phosphorus removal cost efficiencies.

\section{MONITORING RECOMMENDATIONS}

A common monitoring configuration for subsurface drainage denitrifying bioreactors uses pressure transducers with associated dataloggers in the control structures, weir equations, and water quality sampling to estimate nitrate- $\mathrm{N}$ removal. The monitoring methods described below are suggested for conservation practitioners, watershed groups, and others interested in documenting annual nitrate-N load removal for bed-style bioreactors. Beyond this guidance, specific methods for research studies should be guided by the study objectives. Additionally, while the recommended guidance below is for assessment of $\mathrm{N}$ load reductions, water quality sampling alone, without flow monitoring, can provide a simple practitioner-oriented assessment of the reduction in nitrate concentrations across the bioreactor (i.e., indicate if the bioreactor is working).

\section{FLOW MONITORING}

Control structures using stop logs that act as weirs to direct and control flow provide convenient locations to monitor bioreactor flow and water chemistry (fig. 3; USDA, 2012). Water in the control structures cascades over the top stop log, and the water depth is recorded with a pressure transducer placed upstream of the stop log. The pressure transducer either has an internal datalogger or is connected to an external datalogger. That recorded water height is then entered into a calibrated weir equation to calculate the flow rate. While the estimation of flow through control structures in this way violates many of the conditions for standard weir equations, the use of empirically developed weir equations for control structures has proven effective in practice. In some bioreactor installations, a single combined control structure is used to manage inflow, bypass, and outflow. However, it is difficult to measure multiple flows within the small volume of the control structure, so if monitoring flow is an objective, separate inflow and outflow control structures are strongly recommended.

In common monitoring configurations for subsurface drainage bioreactors where two-chamber control structures are used at both the inlet and outlet, neither the bioreactor inflow volume nor the total flow volume from the field are measured (e.g., fig. 3). It is a common misconception that the pressure transducer placed in the inflow control structure yields water depths that can be used to calculate the bioreactor inflow. The pressure transducer placed in the inflow structure is used to estimate the bypass flow, and the pressure transducer placed in the outflow control structure is used to estimate the bioreactor outflow. This is because the pressure transducer data must be paired with a weir equation to convert the logged pressures (that is, the water depths) into flow rates. Total drainage flow from the field is estimated as the bypass flow plus the bioreactor outflow because those two individual flows are generally the only two monitored. In other words, the bypass flow and the bioreactor outflow are the only two streams flowing over a stop log weir in a given control structure. The bioreactor inflow is then usually assumed to be equal to the bioreactor outflow. This assumes that there are no gains or losses of water within the

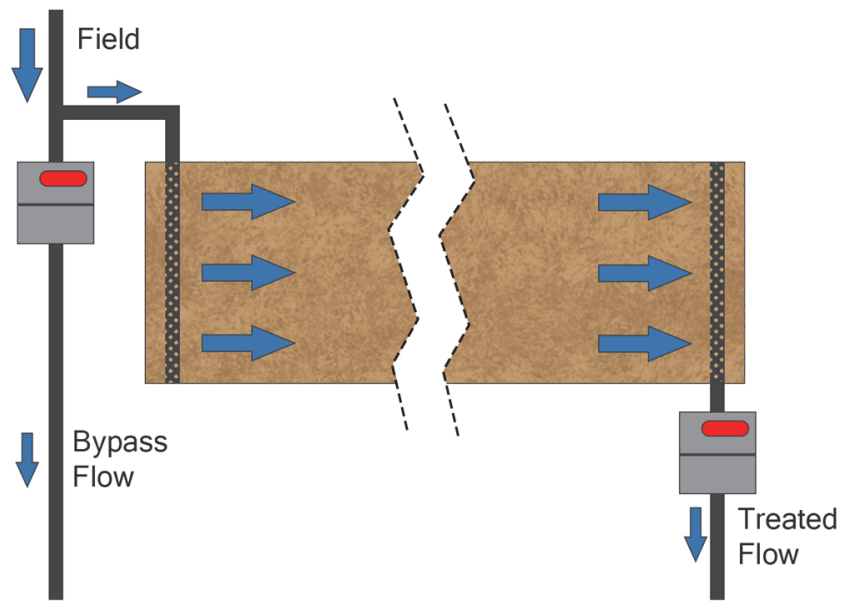

Figure 3. Example placement of pressure transducers (red ovals) in the inflow and outflow control structures for monitoring bypass flow and bioreactor outflow, respectively. Total flow from the field is often calculated as bypass flow volume + bioreactor outflow volume. 
bioreactor; therefore, for monitoring flow, a lined bioreactor design is preferred to make this assumption more valid. Individually monitoring the total flow from the field and/or the bioreactor inflow would require more expensive instrumentation as well as more elaborate plumbing (e.g., additional control structures). Placing the pressure transducers as shown in figure 3 is also a convenient way to estimate the saturated volume of the bioreactor.

It is recommended that the pressure transducers are calibrated and validated in house (e.g., using a flat-bottom bucket) prior to deployment. If the pressure transducers are not vented, a barometric logger needs to be used to correct the logged pressures for changes in barometric pressure; some anecdotal evidence indicates that pressure transducers that internally account for barometric pressure may be simpler. Each pressure transducer should be secured firmly within the control structure, so it does not move. The calculation of water depth flowing over the stop log weir is a relative calculation based on the logged depth of water minus the height of the stop log. Any potential change in elevation of the pressure transducer due to disturbance can result in an inappropriately logged water depth, which would give a false resulting depth of water flowing over the stop log. The pressure transducer can be attached (e.g., zip-tied) to the bottom of a tall "L" made of PVC pipe. The top of the "L" should be screwed or otherwise secured to the inside of the control structure to minimize movement.

It is also recommended that the depth of water on the upstream side of the control structures is manually measured and recorded during each site visit (see example field log sheet in fig. A1 in the Appendix). Continuously logging pressure transducers provide relatively high-frequency water depth data for use in weir equations, but the data should be verified with manual readings, especially if the pressure transducers have moved or if there is accumulated sediment in the structure. Control structure water depths can be manually estimated by applying KolorKut paste to a tape measure or measuring rod, which is then inserted to the bottom of the control structure. A more expensive but more precise option is to use an electronic tape to measure the depth of the water table to the top edge of the control structure.

It is helpful to record the heights of the stop logs in the control structures as often as possible and account for all management activities that alter these heights (fig. A1) because the calculation of water depth flowing over the stop $\log$ weir is a relative calculation involving the total height of the stop logs. A pressure transducer will log the entire depth of water (i.e., pressure) in the control structure, but only the depth of water flowing over the weir is used in the weir equation. Thus, having an exact and current account of (1) the number of stop logs and (2) the height of each stop log is critical for this weir-based flow estimation method.

Selection of the appropriate weir equation can vary based on the type and size of the control structure, the type of stop logs used, and the amount of flow. Chun and Cooke (2008) developed rectangular weir equations for use with standard rectangular stop logs. Their set of equations includes lowflow and high-flow equations for use with $15.2 \mathrm{~cm}$ (6 in.) control structures and low-flow and high-flow equations for structures that are 20.3 to $61.0 \mathrm{~cm}$ ( 8 to $24 \mathrm{in}$.). V-notch weir stop logs with a sharp-crested, stainless-steel edge and the associated flow equation have recently been developed (Christianson et al., 2019). A compound weir equation should be used for when the water height exceeds the top of the V-notch weir plate. In-house calibration of weirs is always recommended. It is not unusual for poorly drained areas where bioreactors are implemented to become submerged. In those cases, it can be difficult to accurately estimate flow, and an orifice approach is recommended (e.g., Cooke et al., 2004). Given that many bioreactors are placed at lower landscape locations that are prone to flooding, it is suggested that researchers describe how flooding events are handled in data processing.

Other flow monitoring methods include the use of area velocity meters with propellers or ultrasonic doppler water velocity measures. The former has moving parts and, in the authors' experience, can be subject to erroneous readings if flow is hampered (e.g., sediment interference). Other anecdotal experience has indicated that ultrasonic velocity meters may have challenges with subsurface drainage water due to the characteristic low turbidity. In locations where the bioreactor is pumped, a mechanical flowmeter of appropriate size may be the most reliable option. In cases where the bioreactor has a clear and accessible outlet, a calibrated bucket and stopwatch can be a low-tech monitoring option. If monitoring funding only allows grab sample collection, replicated bucket and stopwatch flow measurements, taken when water samples are collected, will give a snapshot flow estimate that, while not a complete picture of flow and load reduction performance, can be useful to assess bioreactor performance more thoroughly than just water quality sampling alone.

\section{WATER ChEMISTRY SAMPLING}

Water chemistry sampling and analysis should be performed on bioreactor inflow and outflow water to determine nutrient concentrations, which, when combined with flow data, allow calculation of loading reductions. Nutrient concentrations sampled in the inflow structure are generally applied to calculate both inflow loading and bypass loading. In other words, it is assumed that the nutrient concentration in the bypass flow water does not change between the inflow control structure and the receiving water body. There has been some evidence that nitrate concentrations in the control structures can stratify (Rendall, 2015); therefore, it is important to collect samples in the same way during each sample event.

When the objective is to monitor annual $\mathrm{N}$ loading in subsurface drainage (or in this case, annual $\mathrm{N}$ loading reduction due to a bioreactor), weekly samples for nitrate analysis have generally been recommend. Wang et al. (2003) found that there was a $92 \%$ probability of estimating the annual nitrate$\mathrm{N}$ mass loss within $\pm 15 \%$ of the "true" value with weekly sampling versus a $68 \%$ probability for monthly sampling. Williams et al. (2015) refined this finding by recommending that nitrate-N samples be collected every 2.7 to $6.0 \mathrm{~d}$ for a $\pm 10 \%$ desired uncertainty in tile drainage nitrate loading (or every 1.6 to $1.8 \mathrm{~d}$ for a $\pm 5 \%$ desired uncertainty). Sampling to capture phosphorus dynamics requires increased frequency (e.g., every 13 to $26 \mathrm{~h}$; Williams et al., 2015). 
Capturing more finite changes in water chemistry and variations in bioreactor performance due to fluctuating environmental parameters would require higher-resolution sampling to meet study objectives (even beyond auto-sampler capability). Such enhanced frequency is now possible with more real-time and/or continuous sensors (e.g., Maxwell et al., 2019), although these methods are not yet widely used. An emerging alternative approach is diffuse gradients through thin films (DGT), which are relatively simple devices based on Fick's law of diffusion. Corbett et al. (2020) demonstrated that DGT accurately captured average nitrate concentrations over a $24 \mathrm{~h}$ period along the length of two bioreactors and allowed calculation of removal rates.

A combined inflow-outflow control structure is sometimes used to minimize the cost of purchasing two control structures (e.g., David et al., 2016). This configuration may not be ideal for monitoring nutrient removal performance, as the single control structure necessarily mixes bypass and bioreactor outflow during higher-flow events, making it very difficult to sample those flows separately during those times. As mentioned above, separate inflow and outflow control structures are recommended for bioreactors that are intended to be monitored.

\section{DATA REPORTING}

Collection and reporting of a minimum set of consistent criteria at field sites would advance denitrifying bioreactor science and engineering (table 1). Several years ago, Christianson and Schipper (2016) suggested that the research community would benefit from publication of bioreactor performance data in more original forms to allow testing of models and for development of future hypotheses. They suggested, at minimum, inclusion of bioreactor location, installation date, and nitrate concentration, flow, and temperature data. Those suggestions are reiterated here along with additional measures depending on funding and staffing capabilities. Recent bioreactor monitoring guidance from Queensland recommends "core" and "satellite" bioreactor sites with appropriate levels of monitoring at each site (Queensland, 2018). Table 1 follows a similar idea with three levels of monitoring, again depending on funding and capacity. For practitioners, the "minimum suggested to report" is particularly important; it may be better to have as many bioreactors as possible consistently reporting basic information compared to fewer sites where data may be more in-depth but more case-study in nature.

The 2016 recommendations urged tandem reporting of $\mathrm{N}$ removal rate ( $\mathrm{g}$ nitrate- $\mathrm{N}$ removed per $\mathrm{m}^{3}$ of bioreactor per d) and $\mathrm{N}$ removal efficiency (\% reduction; Christianson and Schipper, 2016), and the latter is now been expanded to include explicit masses of $\mathrm{N}$ removed $\left(\mathrm{kg} \mathrm{N} ; \mathrm{kg} \mathrm{N} \mathrm{ha}^{-1}\right)$ and flow volumes treated $\left(\mathrm{m}^{3} ; \mathrm{mm}\right.$ equivalent depth). The method of calculating the removal rate and hydraulic retention time should be made explicit, including use of the entire reactor volume or the saturated reactor volume (when the entire bed is not saturated) and use of the total or effective/drainable porosity. Additional monitoring and reporting guidance is needed for denitrifying walls and in-ditch bioreactors. While the recommendations in table 1 generally apply, specific nuances, such as flow estimates for shallow groundwater at denitrifying walls, require special attention.

\section{Conclusions}

Denitrifying bioreactors are an effective and cost-efficient technology for treatment of nitrate in subsurface drainage and other waters. This review documents a variety of successes with and some limitations of full-scale bioreactors for a variety of applications around the world. An evaluation across peer-reviewed literature published over the past three

Table 1. Three levels of suggested reporting criteria for field-scale bioreactors treating agricultural drainage. This could be easily modified to report data from other types of full-size bioreactors (e.g., aquacultural wastewater) that are influenced similarly by field conditions. HRT is hydraulic retention time; ORP is oxidation-reduction potential.

\begin{tabular}{|c|c|c|c|}
\hline $\begin{array}{l}\text { Reporting } \\
\text { Type }\end{array}$ & $\begin{array}{c}\text { Minimum } \\
\text { Suggested to Report }\end{array}$ & $\begin{array}{c}\text { Suggested } \\
\text { Additional Reporting }\end{array}$ & $\begin{array}{l}\text { Supplemental Suggestions for Future } \\
\text { Modeling or Meta-Analytical Work }\end{array}$ \\
\hline $\begin{array}{c}\text { In-field } \\
\text { characteristics }\end{array}$ & $\begin{array}{l}\text { Known or estimated drainage area, } \\
\text { drainage criteria for bioreactor design } \\
\text { capacity per NRCS standard, presence } \\
\text { of surface inlets, and cropping system } \\
\text { rotation or land use. }\end{array}$ & $\begin{array}{l}\text { Additional drainage details (pattern } \\
\text { or targeted drainage system, drain } \\
\text { spacing and depth, drainage coeffi- } \\
\text { cient, drainage management zones) } \\
\text { and soil types in drainage area. }\end{array}$ & $\begin{array}{l}\text { Field management information: nutrients } \\
\text { (source, timing, rate, and placement), tillage, } \\
\text { planting and harvesting dates, crop yield, cover } \\
\text { crop information, and additional drainage } \\
\text { details (e.g., drainage intensity; Skaggs, 2017). }\end{array}$ \\
\hline $\begin{array}{l}\text { Bioreactor } \\
\text { design }\end{array}$ & $\begin{array}{l}\text { Bioreactor dimensions }(\mathrm{L} \times \mathrm{W} \times \mathrm{D} \text {, where } \\
\mathrm{D} \text { is depth of woodchips) and volume, } \\
\text { installation date, design HRT and design } \\
\text { flow rate (or associated criteria), and } \\
\text { presence/absence of soil cover. }\end{array}$ & $\begin{array}{l}\text { Typical saturation depth, in situ } \\
\text { HRT, manifold orientation and flow } \\
\text { direction (e.g., upflow, downflow, } \\
\text { and horizontal flow), and stop log } \\
\text { management. }\end{array}$ & $\begin{array}{c}\text { As-built survey indicating elevations of all } \\
\text { bioreactor components, and conservative } \\
\text { tracer testing metrics such as hydraulic } \\
\text { efficiency. }\end{array}$ \\
\hline $\begin{array}{l}\text { Bioreactor } \\
\quad \text { fill }\end{array}$ & $\begin{array}{l}\text { Size range for most of the media, } \\
\text { estimated drainable porosity, and } \\
\text { general type (hardwood/softwood). }\end{array}$ & $\begin{array}{l}\text { Particle } \mathrm{D}_{10} \text { and } \mathrm{D}_{50} \text {, particle } \\
\text { uniformity coefficient, bulk density, } \\
\text { total porosity, wood species, } \\
\text { and general woodchip shape (e.g., } \\
\text { irregular, rectangular, flat, square). }\end{array}$ & $\begin{array}{c}\text { Full particle size distribution, saturated } \\
\text { hydraulic conductivity, estimate of carbon source } \\
\text { longevity, and type of wood- } \\
\text { chipping equipment. }\end{array}$ \\
\hline $\begin{array}{l}\text { Water chemistry } \\
\text { and quality }{ }^{[\mathrm{a}]}\end{array}$ & $\begin{array}{l}\text { Nitrate-N concentrations } \\
\text { and water temperature. }\end{array}$ & Dissolved oxygen and $\mathrm{pH}$. & $\begin{array}{l}\text { ORP, total nitrogen, dissolved organic carbon, } \\
\text { sulfate, total and/or dissolved phosphorus, } \\
\text { methyl mercury, and additional pollutants. }\end{array}$ \\
\hline Flow criteria & $\begin{array}{l}\text { Bioreactor flow rates and volume } \\
\text { and/or percentage of water treated. }\end{array}$ & $\begin{array}{l}\text { Precipitation during } \\
\text { monitoring period. }\end{array}$ & Long-term average annual precipitation. \\
\hline $\begin{array}{l}\text { Performance } \\
\text { criteria }\end{array}$ & $\begin{array}{l}\mathrm{N} \text { removal rate, } \mathrm{N} \text { removal efficiency, } \\
\text { and undesirable effects over time (e.g., } \\
\text { early slumping, flow restriction). }\end{array}$ & $\begin{array}{l}\text { Mass load/loss from the field, } \\
\text { mass load/loss removed, and } \\
\text { mass load/loss bypassing. }\end{array}$ & $\begin{array}{l}\text { Load reduction of phosphorus } \\
\text { or other contaminants. }\end{array}$ \\
\hline
\end{tabular}

[a] Generally for the inflow and outflow; additional internal measurements are desirable supplemental information. 
years showed that bed-style bioreactors provided $40 \% \pm 26 \%$ $\mathrm{N}$ load reduction (mean $\pm \mathrm{SD}$; median: $46 \% ; n=15$; $\mathrm{N}$ removal rate mean \pm SD: $7.2 \pm 9.6 \mathrm{~g} \mathrm{~N} \mathrm{~m}^{-3} \mathrm{~d}^{-1} ; n=27$ ). Bioreactors designed to any given standard may not achieve this mean value consistently, as this analysis included a variety of bioreactors treating a range of water matrices. Installation costs for subsurface drainage bioreactors have ranged from less than $\$ 5,000$ to $\$ 27,000$, with estimated cost efficiencies ranging from less than $\$ 2.50 \mathrm{~kg}^{-1} \mathrm{~N}$ to about $\$ 20 \mathrm{~kg}^{-1} \mathrm{~N}$. Bioreactors in high-solids applications (i.e., not subsurface drainage) provide effective solids and sediment removal, but there are little field-scale data on this. Denitrifying bioreactors treating subsurface drainage show a mix of phosphorus leaching and removal, although most bioreactors generally experience phosphorus leaching at start-up. The mechanisms and consistency of these phosphorus dynamics are unclear.

Despite $\mathrm{N}$ removal successes, there is much room to advance the science and engineering of bioreactor technology. Key research areas include: improving understanding of removal of additional pollutants, compounds, and biologicals; reducing pollution swapping especially at start-up; advances to simplify and streamline the design process; innovative design modifications; and development of management strategies to address observed challenges such as clogging and slumping. Moving this field forward requires more strategic and coordinated monitoring efforts as new bioreactors continue to be designed and constructed. A suggested monitoring setup is described for assessing the annual nitrate- $\mathrm{N}$ load removal performance of subsurface drainage denitrifying bioreactors. Recommended minimum reporting measures include: bioreactor dimensions and installation date; fill media size, porosity, and type; nitrate-N concentrations and water temperature; bioreactor flow treatment details; basic in-field cropping and drainage system characteristics; and $\mathrm{N}$ removal rate and efficiency.

\section{ACKNOWLEDGEMENTS}

The first author gratefully acknowledges funding and support from USDA Hatch Project ILLU-802-925 and Project NR185A12XXXXC004 CESU under Great Rivers Umbrella Agreement 68-3A75-18-504 (USDA-NRCS). The third author was funded by the soybean checkoff through the Iowa Soybean Association.

\section{REFERENCES}

ABC Rural News. (2020). Researchers and farmers join forces in bid to save Great Barrier Reef from fertiliser run-off. ABC Rural News (11 March 2020). Ultimo, NSW, Australia: Australian Broadcasting Corporation. Retrieved from https://www.abc.net.au/news/rural/2020-03-11/new-tool-tofight-great-barrier-reef-runoff-examined-at-cairns/12044942

Addy, K., Gold, A. J., Christianson, L. E., David, M. B., Schipper, L. A., \& Ratigan, N. A. (2016). Denitrifying bioreactors for nitrate removal: A meta-analysis. J. Environ. Qual., 45(3), 873881. https://doi.org/10.2134/jeq2015.07.0399

Australia. (2018). The Reef 2050 Long-Term Sustainability Plan. Canberra, ACT, Australia: Government of Australia, Department of Agriculture, Water, and the Environment. Retrieved from http://www.environment.gov.au/marine/gbr/long-termsustainability-plan

Barkle, G. F., Schipper, L. A., Burgess, C. P., \& Painter, B. D. (2008). In situ mixing of organic matter decreases hydraulic conductivity of denitrification walls in sand aquifers. Groundwater Monit. Remed., 28(1), 57-64. https://doi.org/10.1111/j.1745-6592.2007.00185.x

Bell, N. L. (2019). Evaluation of the potential for ecological treatment technologies to remediate species of Phytophthora from irrigation runoff. $\mathrm{PhD}$ diss. Clemson, SC: Clemson University.

Bell, N., Cooke, R. A., Olsen, T., David, M. B., \& Hudson, R. (2015). Characterizing the performance of denitrifying bioreactors during simulated subsurface drainage events. $J$. Environ. Qual., 44(5), 1647-1656. https://doi.org/10.2134/jeq2014.04.0162

Bock, E. M., Coleman, B. S. L., \& Easton, Z. M. (2018). Performance of an under-loaded denitrifying bioreactor with biochar amendment. J. Environ. Mgmt., 217, 447-455. https://doi.org/10.1016/j.jenvman.2018.03.111

Bruun, J., Hoffmann, C. C., \& Kjaergaard, C. (2017). Convective transport of dissolved gases determines the fate of the greenhouse gases produced in reactive drainage filters. Ecol. Eng., 98, 1-10. https://doi.org/10.1016/j.ecoleng.2016.10.027

Bruun, J., Pugliese, L., Hoffmann, C. C., \& Kjaergaard, C. (2016). Solute transport and nitrate removal in full-scale subsurface flow constructed wetlands of various designs treating agricultural drainage water. Ecol. Eng., 97, 88-97. https://doi.org/10.1016/j.ecoleng.2016.07.010

Bryant, R., Baldwin, A., Cahall, B., Christianson, L., Jaynes, D., Penn, C., \& Schwartz., S. (2019). Best management practices for agricultural ditch management in the Phase 6 Chesapeake Bay Watershed Model. Report No. CBP/TRS-326-19. Annapolis, MD: Chesapeake Bay Program.

Cameron, S. G., \& Schipper, L. A. (2010). Nitrate removal and hydraulic performance of organic carbon for use in denitrification beds. Ecol. Eng., 36(11), 1588-1595. https://doi.org/10.1016/j.ecoleng.2010.03.010

Cameron, S. G., \& Schipper, L. A. (2011). Evaluation of passive solar heating and alternative flow regimes on nitrate removal in denitrification beds. Ecol. Eng., 37(8), 1195-1204.

https://doi.org/10.1016/j.ecoleng.2011.02.020

Chase, E. H., Schneider, R. L., Baker, N. J., \& Dunn, S. J. (2019). Retrofitting the rural roadside ditch network to treat nitrogen from agricultural runoff using woodchip bioreactors. Proc. 12th Intl. Conf. on Low-Volume Roads. Washington, DC: Transportation Research Board.

Choudhury, T., Robertson, W. D., \& Finnigan, D. S. (2016). Suspended sediment and phosphorus removal in a woodchip filter system treating agricultural wash water. J. Environ. Qual., 45(3), 796-802. https://doi.org/10.2134/jeq2015.07.0380

Christianson, L. E., \& Schipper, L. A. (2016). Moving denitrifying bioreactors beyond proof of concept: Introduction to the special section. J. Environ. Qual., 45(3), 757-761. https://doi.org/10.2134/jeq2016.01.0013

Christianson, L. E., Bhandari, A., \& Helmers, M. J. (2012a). A practice-oriented review of woodchip bioreactors for subsurface agricultural drainage. Appl. Eng. Agric., 28(6), 861-874. https://doi.org/10.13031/2013.42479

Christianson, L. E., Christianson, R. D., Lipka, A. E., Bailey, S., Chandrasoma, J., McCoy, C., ... Cooke, R. A. (2019). Calibration of stainless steel-edged V-notch weir stop logs for water level control structures. Appl. Eng. Agric., 35(5), 745-749. https://doi.org/10.13031/aea.13350

Christianson, L. E., Collick, A. S., Bryant, R. B., Rosen, T., Bock, E. M., Allen, A. L., ... Easton, Z. M. (2017). Enhanced 
denitrification bioreactors hold promise for Mid-Atlantic ditch drainage. Agric. Environ. Letters, 2(1), article 170032. https://doi.org/10.2134/ael2017.09.0032

Christianson, L. E., Feyereisen, G. W., Hay, C., Tschirner, U. W., Kult, K., Wickramarathne, N. M., ... Soupir, M. L. (2020). Denitrifying bioreactor woodchip recharge: Media properties after nine years. Trans. ASABE, 63(2), 407-416. https://doi.org/10.13031/trans.13709

Christianson, L. E., Lepine, C., Sharrer, K. L., \& Summerfelt, S. T. (2016). Denitrifying bioreactor clogging potential during wastewater treatment. Water Res., 105, 147-156. https://doi.org/10.1016/j.watres.2016.08.067

Christianson, L., Bhandari, A., Helmers, M., Kult, K., Sutphin, T., \& Wolf, R. (2012b). Performance evaluation of four field-scale agricultural drainage denitrification bioreactors in Iowa. Trans. ASABE, 55(6), 2163-2174. https://doi.org/10.13031/2013.42508

Christianson, L., Tyndall, J., \& Helmers, M. (2013). Financial comparison of seven nitrate reduction strategies for Midwestern agricultural drainage. Water Resour. Econ., 2-3, 30-56. https://doi.org/10.1016/j.wre.2013.09.001

Chun, J. A., \& Cooke, R. A. (2008). Technical note: Calibrating agridrain water level control structures using generalized weir and orifice equations. Appl. Eng. Agric., 24(5), 595-602. https://doi.org/10.13031/2013.25274

Clagnan, E., Thornton, S. F., Rolfe, S. A., Tuohy, P., Peyton, D., Wells, N. S., \& Fenton, O. (2018). Influence of artificial drainage system design on the nitrogen attenuation potential of gley soils: Evidence from hydrochemical and isotope studies under field-scale conditions. J. Environ. Mgmt., 206, 1028-1038. https://doi.org/10.1016/j.jenvman.2017.11.069

Cooke, R. A., \& Bell, N. L. (2014). Protocol and interactive routine for the design of subsurface bioreactors. Appl. Eng. Agric., 30(5), 761-771. https://doi.org/10.13031/aea.30.9900

Cooke, R. A., Doheny, A. M., \& Hirschi, M. C. (2001). Bioreactors for edge-of-field treatment of tile outflow. ASABE Paper No. 012018. St. Joseph, MI: ASABE. https://doi.org/10.13031/2013.7373

Cooke, R., Wildman, T., \& Northcott, W. (2004). Accurate, lowcost instrument for measuring subsurface drain flow under submerged outlet conditions. Proc. 8th Intl. Drainage Symp. St. Joseph, MI: ASAE.

Corbett, T. D., Dougherty, H., Maxwell, B., Hartland, A., Henderson, W., Rys, G. J., \& Schipper, L. A. (2020). Utility of "diffusive gradients in thin-films" for the measurement of nitrate removal performance of denitrifying bioreactors. Sci. Total Environ., 718, article 135267. https://doi.org/10.1016/j.scitotenv.2019.135267

David, M. B., Gentry, L. E., Cooke, R. A., \& Herbstritt, S. M. (2016). Temperature and substrate control woodchip bioreactor performance in reducing tile nitrate loads in east-central Illinois. J. Environ. Qual., 45(3), 822-829. https://doi.org/10.2134/jeq2015.06.0296

DeBoe, G., Bock, E., Stephenson, K., \& Easton, Z. (2017). Nutrient biofilters in the Virginia coastal plain: Nitrogen removal, cost, and potential adoption pathways. J. Soil Water Cons., 72(2), 139-149. https://doi.org/10.2489/jswc.72.2.139

Dhaese, K., Koopmans, K., Luys, L., Palmans, S., Christianson, L. E., \& Nelissen, V. (2019). Nitrate removal rate in an "in-ditch" bioreactor in Flanders (Belgium). Proc. 4th Intl. Interdisciplinary Conf. on Land Use and Water Quality: Agriculture and the Environment. Aarhus, Denmark: Aarhus University, Danish Center for Environment and Energy. Retrieved from

https://www.luwq2019.dk/upload/LuWQ2019_abstracts_oral_a nd_poster_for_web_306_28Mar2019.pdf
Dougherty, H. (2018). Hydraulic evaluation of a denitrifying bioreactor with baffles. MS thesis. Urbana, IL: University of Illinois.

Easton, Z. M., Bock, E., \& Stephenson, K. (2019). Feasibility of using woodchip bioreactors to treat legacy nitrogen to meet Chesapeake Bay water quality goals. Environ. Sci. Tech., 53(21), 12291-12299. https://doi.org/10.1021/acs.est.9b04919

Elgood, Z., Robertson, W. D., Schiff, S. L., \& Elgood, R. (2010). Nitrate removal and greenhouse gas production in a stream-bed denitrifying reactor. Ecol. Eng., 36(11), 1575-1580. https://doi.org/10.1016/j.ecoleng.2010.03.011

EU. (1991). Council Directive 91/676/EEC concerning the protection of waters against pollution caused by nitrates from agricultural sources. Brussels, Belgium: Council of the European Union. Retrieved from https://eur-lex.europa.eu/legalcontent/EN/TXT/PDF/?uri=CELEX:31991L0676\&from=EN

Fahrner, S. (2002). Groundwater nitrate removal using a bioremediation trench. Honours thesis. Perth, Australia: University of Western Australia.

Feyereisen, G. W., Moorman, T. B., Christianson, L. E., Venterea, R. T., Coulter, J. A., \& Tschirner, U. W. (2016). Performance of agricultural residue media in laboratory denitrifying bioreactors at low temperatures. J. Environ. Qual., 45(3), 779-787. https://doi.org/10.2134/jeq2015.07.0407

Gibert, O., Pomierny, S., Rowe, I., \& Kalin, R. M. (2008). Selection of organic substrates as potential reactive materials for use in a denitrification permeable reactive barrier (PRB). Bioresour. Tech., 99(16), 7587-7596. https://doi.org/10.1016/j.biortech.2008.02.012

Goeller, B. C., Burbery, L. F., Febria, C. M., Collins, K. E., Burrows, N. J., Simon, K. S., ... McIntosh, A. R. (2019). Capacity for bioreactors and riparian rehabilitation to enhance nitrate attenuation in agricultural streams. Ecol. Eng., 134, 6577. https://doi.org/10.1016/j.ecoleng.2019.03.014

Goodwin, G. E., Bhattarai, R., \& Cooke, R. (2015). Synergism in nitrate and orthophosphate removal in subsurface bioreactors. Ecol. Eng., 84, 559-568. https://doi.org/10.1016/j.ecoleng.2015.09.051

Gottschall, N., Edwards, M., Craiovan, E., Frey, S. K., Sunohara, M., Ball, B., ... Lapen, D. R. (2016). Amending woodchip bioreactors with water treatment plant residuals to treat nitrogen, phosphorus, and veterinary antibiotic compounds in tile drainage. Ecol. Eng., 95, 852-864. https://doi.org/10.1016/j.ecoleng.2016.06.011

Hassanpour, B., Giri, S., Pluer, W. T., Steenhuis, T. S., \& Geohring, L. D. (2017). Seasonal performance of denitrifying bioreactors in the northeastern United States: Field trials. J. Environ. Mgmt., 202, 242-253. https://doi.org/10.1016/j.jenvman.2017.06.054

Hassanpour, B., Geohring, L. D., Klein, A. R., Giri, S., Aristilde, L., \& Steenhuis, T. S. (2019). Application of denitrifying bioreactors for the removal of atrazine in agricultural drainage water. J. Environ. Mgmt., 239, 48-56. https://doi.org/10.1016/j.jenvman.2019.03.029

Healy, M. G., Ibrahim, T. G., Lanigan, G. J., Serrenho, A. J., \& Fenton, O. (2012). Nitrate removal rate, efficiency, and pollution swapping potential of different organic carbon media in laboratory denitrification bioreactors. Ecol. Eng., 40, 198-209. https://doi.org/10.1016/j.ecoleng.2011.12.010

Hoffmann, C. C., Larsen, S. E., \& Kjaergaard, C. (2019). Nitrogen removal in woodchip-based biofilters of variable designs treating agricultural drainage discharges. J. Environ. Qual., 48(6), 1881-1889. https://doi.org/10.2134/jeq2018.12.0442

Hua, G., Salo, M. W., Schmit, C. G., \& Hay, C. H. (2016). Nitrate and phosphate removal from agricultural subsurface drainage using laboratory woodchip bioreactors and recycled steel 
byproduct filters. Water Res., 102, 180-189. https://doi.org/10.1016/j.watres.2016.06.022

Hudson, R. J., \& Cooke, R. A. (2015). Methylmercury production in denitrifying woodchip bioreactors. Report RR-130. Champaign, IL: University of Illinois, Illinois Sustainable Technology Center. Retrieved from http://hdl.handle.net/2142/88352

Husk, B. R., Anderson, B. C., Whalen, J. K., \& Sanchez, J. S. (2017). Reducing nitrogen contamination from agricultural subsurface drainage with denitrification bioreactors and controlled drainage. Biosyst. Eng., 153, 52-62. https://doi.org/10.1016/j.biosystemseng.2016.10.021

Husk, B. R., Sanchez, J. S., Anderson, B. C., Whalen, J. K., \& Wootton, B. C. (2018). Removal of phosphorus from agricultural subsurface drainage water with woodchip and mixed-media bioreactors. J. Soil Water Cons., 73(3), 265-275. https://doi.org/10.2489/jswc.73.3.265

IDALS. (2014). Iowa Nutrient Reduction Strategy: A science and technology-based framework to assess and reduce nutrients to Iowa waters and the Gulf of Mexico. Des Moines, IA: Iowa Department of Agriculture and Land Stewardship.

IDALS. (2019). Iowa Nutrient Reduction Strategy: 2017-18 annual progress report (INRC 0016A). Des Moines: Iowa Department of Agriculture and Land Stewardship.

IDOA. (2015). Illinois Nutrient Loss Reduction Strategy. Springfield, IL: Illinois Department of Agriculture and Illinois Environmental Protection Agency.

IDOA and IEPA. (2019). Illinois Nutrient Loss Reduction Strategy: Biennial report 2019. Springfield, IL: Illinois Department of Agriculture and Illinois Environmental Protection Agency.

Ilhan, Z. E., Ong, S. K., \& Moorman, T. B. (2011). Dissipation of atrazine, enrofloxacin, and sulfamethazine in wood chip bioreactors and impact on denitrification. J. Environ. Qual., 40(6), 1816-1823. https://doi.org/10.2134/jeq2011.0082

Jang, C., Gautam, S., Cooke, R. A. C., \& Bhattarai, R. (2018). Development of a process-based subsurface bioreactor model. ASABE Paper No. 1800947. St. Joseph, MI: ASABE. https://doi.org/10.13031/aim.201800947

Jaynes, D. B., Kaspar, T. C., Moorman, T. B., \& Parkin, T. B. (2008). In situ bioreactors and deep drain-pipe installation to reduce nitrate losses in artificially drained fields. J. Environ. Qual., 37(2), 429-436. https://doi.org/10.2134/jeq2007.0279

Jones, C. S., \& Kult, K. J. (2016). Use alkalinity monitoring to optimize bioreactor performance. J. Environ. Qual., 45(3), 855865. https://doi.org/10.2134/jeq2015.06.0309

Krause Camilo, B., Matzinger, A., Litz, N., Tedesco, L. P., \& Wessolek, G. (2013). Concurrent nitrate and atrazine retention in bioreactors of straw and bark mulch at short hydraulic residence times. Ecol. Eng., 55, 101-113.

https://doi.org/10.1016/j.ecoleng.2013.02.010

Lepine, C., Christianson, L., Davidson, J., \& Summerfelt, S. (2018). Woodchip bioreactors as treatment for recirculating aquaculture systems' wastewater: A cost assessment of nitrogen removal. Aquacult. Eng., 83, 85-92. https://doi.org/10.1016/j.aquaeng.2018.09.001

Lepine, C., Christianson, L., McIsaac, G., \& Summerfelt, S. (2020a). Denitrifying bioreactor inflow manifold design for treatment of aquacultural wastewater. Aquacult. Eng., 88, 102036. https://doi.org/10.1016/j.aquaeng.2019.102036

Lepine, C., Christianson, L., Soucek, D., McIsaac, G., \& Summerfelt, S. (2020b). Solute metal leaching and ecotoxicity of denitrifying woodchip bioreactor outflow: Potential reuse of effluent water. Aquaculture, article 102129. https://doi.org/10.1016/j.aquaeng.2020.102129

Li, S., Cooke, R. A., Huang, X., Christianson, L., \& Bhattarai, R. (2018). Evaluation of fly ash pellets for phosphorus removal in a laboratory-scale denitrifying bioreactor. J. Environ. Mgmt., 207, 269-275. https://doi.org/10.1016/j.jenvman.2017.11.040

Liu, Y., Ptacek, C. J., \& Blowes, D. W. (2014). Treatment of dissolved perchlorate, nitrate, and sulfate using zero-valent iron and organic carbon. J. Environ. Qual., 43(3), 842-850. https://doi.org/10.2134/jeq2013.03.0077

Long, L. M., Schipper, L. A., \& Bruesewitz, D. A. (2011). Longterm nitrate removal in a denitrification wall. Agric. Ecosyst. Environ., 140(3), 514-520. https://doi.org/10.1016/j.agee.2011.02.005

Manca, F., De Rosa, D., Reading, L. P., Rowlings, D. W., Scheer, C., Layden, I., ... Grace, P. R. (2020). Nitrate removal and greenhouse gas production of woodchip denitrification walls under a humid subtropical climate. Ecol. Eng., 156, 105988. https://doi.org/10.1016/j.ecoleng.2020.105988

Maxwell, B. M., Birgand, F., Schipper, L. A., Christianson, L. E., Tian, S., Helmers, M. J., ... Youssef, M. A. (2019). Dryingrewetting cycles affect nitrate removal rates in woodchip bioreactors. J. Environ. Qual., 48(1), 93-101. https://doi.org/10.2134/jeq2018.05.0199

Moorman, T. B., Parkin, T. B., Kaspar, T. C., \& Jaynes, D. B. (2010). Denitrification activity, wood loss, and $\mathrm{N}_{2} \mathrm{O}$ emissions over nine years from a wood chip bioreactor. Ecol. Eng., 36(11), 1567-1574. https://doi.org/10.1016/j.ecoleng.2010.03.012

Natarajan, M. A. (2015). Mercury methylation in denitrifying bioreactors: An investigation in pollution swapping. MS thesis. St. Paul, MN: University of Minnesota.

Nordström, A., \& Herbert, R. B. (2019). Identification of the temporal control on nitrate removal rate variability in a denitrifying woodchip bioreactor. Ecol. Eng., 127, 88-95. https://doi.org/10.1016/j.ecoleng.2018.11.015

Partheeban, C. (2014). Demonstrating the effectiveness of nitratenitrogen removal of denitrifying bioreactors in South Dakota for improved drainage water management. MS thesis. Brookings, SD: South Dakota State University.

Pfannerstill, M., Kühling, I., Hugenschmidt, C., Trepel, M., \& Fohrer, N. (2016). Reactive ditches: A simple approach to implement denitrifying wood chip bioreactors to reduce nitrate exports into aquatic ecosystems? Environ. Earth Sci., 75(13), 1063. https://doi.org/10.1007/s12665-016-5856-2

Pluer, W. T., Hoffman, R., \& Walter, M. T. (2018). Reducing stormwater nitrogen with denitrifying bioreactors: Florida case study. J. Sustain. Water Built Environ., 4(4), 06018002. https://doi.org/10.1061/JSWBAY.0000867

Pluer, W. T., Morris, C. K., Walter, M. T., \& Geohring, L. D. (2019). Denitrifying bioreactor response during storm events. Agric. Water Mgmt., 213(1), 1109-1115. https://doi.org/10.1016/j.agwat.2018.12.004

Queensland. (2018). Bioreactors: Key aspects for effective design, operation and monitoring. Interim guideline for bioreactor trials July 2018. Brisbane, QLD, Australia: Queensland Government. Retrieved from https://www.publications.qld.gov.au/dataset/c6f486aa-30a14fe9-b5ea-c8894394f989/resource/c83ff8e2-024c-4e0a-8974$10 \mathrm{c} 5 \mathrm{fd} 5994 \mathrm{f} 4$

Rambags, F., Tanner, C. C., \& Schipper, L. A. (2019). Denitrification and anammox remove nitrogen in denitrifying bioreactors. Ecol. Eng., 138, 38-45. https://doi.org/10.1016/j.ecoleng.2019.06.022

Rambags, F., Tanner, C. C., Stott, R., \& Schipper, L. A. (2016). Fecal bacteria, bacteriophage, and nutrient reductions in a fullscale denitrifying woodchip bioreactor. J. Environ. Qual., 45(3), 847-854. https://doi.org/10.2134/jeq2015.06.0326

Ranaivoson, A., Moncrief, J., Venterea, R., Rice, P., \& Dittrich, M. (. (2012). Anaerobic woodchip bioreactor for denitrification, 
herbicide dissipation, and greenhouse gas mitigation. St. Paul, MN: Minnesota Department of Agriculture.

Ranaivoson, A., Rice, P., Moncrief, J. F., Feyereisen, G. W., \& Dittrich, M. (2019). Acetochlor and atrazine dissipation in a woodchip denitrifying bioreactor: A comparison of experimental results with model estimates. Intl. J. Hydrol., 3(4), 286-306.

Rendall, T. J. (2015). Effect of passive and active heating on the performance of denitrifying bioreactors. MS thesis. Urbana, IL: University of Illinois.

Robertson, W. D., \& Merkley, L. C. (2009). In-stream bioreactor for agricultural nitrate treatment. J. Environ. Qual., 38(1), 230237. https://doi.org/10.2134/jeq2008.0100

Robertson, W. D., Blowes, D. W., Ptacek, C. J., \& Cherry, J. A. (2000). Long-term performance of in situ reactive barriers for nitrate remediation. Groundwater, 38(5), 689-695. https://doi.org/10.1111/j.1745-6584.2000.tb02704.x

Rosen, T., \& Christianson, L. (2017). Performance of denitrifying bioreactors at reducing agricultural nitrogen pollution in a humid subtropical coastal plain climate. Water, 9(2), 112. https://doi.org/10.3390/w9020112

Sarris, T. S., \& Burbery, L. F. (2018). Stochastic multi-objective performance optimization of an in-stream woodchip denitrifying bioreactor. Ecol. Eng., 124, 38-50. https://doi.org/10.1016/j.ecoleng.2018.09.006

Schipper, L. A., \& Vojvodic-Vukovic, M. (2000). Nitrate removal from groundwater and denitrification rates in a porous treatment wall amended with sawdust. Ecol. Eng., 14(3), 269-278. https://doi.org/10.1016/S0925-8574(99)00002-6

Schipper, L. A., Barkle, G. F., \& Vojvodic-Vukovic, M. (2005). Maximum rates of nitrate removal in a denitrification wall. $J$. Environ. Qual., 34(4), 1270-1276. https://doi.org/10.2134/jeq2005.0008

Schipper, L. A., Barkle, G. F., Hadfield, J. C., Vojvodic-Vukovic, M., \& Burgess, C. P. (2004). Hydraulic constraints on the performance of a groundwater denitrification wall for nitrate removal from shallow groundwater. J. Contam. Hydrol., 69(3), 263-279. https://doi.org/10.1016/S0169-7722(03)00157-8

Schipper, L. A., Cameron, S. C., \& Warneke, S. (2010b). Nitrate removal from three different effluents using large-scale denitrification beds. Ecol. Eng., 36(11), 1552-1557. https://doi.org/10.1016/j.ecoleng.2010.02.007

Schipper, L. A., Robertson, W. D., Gold, A. J., Jaynes, D. B., \& Cameron, S. C. (2010a). Denitrifying bioreactors: An approach for reducing nitrate loads to receiving waters. Ecol. Eng., 36(11), 1532-1543. https://doi.org/10.1016/j.ecoleng.2010.04.008

Schipper, L., \& Vojvodic-Vukovic, M. (1998). Nitrate removal from groundwater using a denitrification wall amended with sawdust: Field trial. J. Environ. Qual., 27(3), 664-668. https://doi.org/10.2134/jeq1998.00472425002700030025x

Schmidt, C. A., \& Clark, M. W. (2012). Evaluation of a denitrification wall to reduce surface water nitrogen loads. $J$. Environ. Qual., 41(3), 724-731. https://doi.org/10.2134/jeq2011.0331

Sharpley, A. N., Krogstad, T., Kleinman, P. J., \& Haggard, B. (2007). Managing natural processes in drainage ditches for nonpoint-source phosphorus control. J. Soil Water Cons., 62(4), 197-206.

Sharrer, K. L., Christianson, L. E., Lepine, C., \& Summerfelt, S. T. (2016). Modeling and mitigation of denitrification woodchip bioreactor phosphorus releases during treatment of aquaculture wastewater. Ecol. Eng., 93, 135-143. https://doi.org/10.1016/j.ecoleng.2016.05.019

Shih, R., Robertson, W. D., Schiff, S. L., \& Rudolph, D. L. (2011). Nitrate controls methyl mercury production in a streambed bioreactor. J. Environ. Qual., 40(5), 1586-1592. https://doi.org/10.2134/jeq2011.0072

Skaggs, R. W. (2017). Coefficients for quantifying subsurface drainage rates. Appl. Eng. Agric., 33(6), 793-799. https://doi.org/10.13031/aea.12302

Tanner, C. C., Sukias, J. P., Headley, T. R., Yates, C. R., \& Stott, R. (2012). Constructed wetlands and denitrifying bioreactors for on-site and decentralised wastewater treatment: Comparison of five alternative configurations. Ecol. Eng., 42, 112-123. https://doi.org/10.1016/j.ecoleng.2012.01.022

USDA. (2012). Edge-of-field water quality monitoring system installation - Conservation activity (Code 202). Washington, DC: USDA Natural Resources Conservation Service.

USDA. (2015). Conservation practice standard denitrifying bioreactor code 605 (605-CPS). Washington, DC: USDA Natural Resources Conservation Service.

von Ahnen, M., Pedersen, P. B., \& Dalsgaard, J. (2016). Start-up performance of a woodchip bioreactor operated end-of-pipe at a commercial fish farm: A case study. Aquacult. Eng., 74, 96-104. https://doi.org/10.1016/j.aquaeng.2016.07.002

von Ahnen, M., Pedersen, P. B., \& Dalsgaard, J. (2018). Performance of full-scale woodchip bioreactors treating effluents from commercial RAS. Aquacult. Eng., 83, 130-137. https://doi.org/10.1016/j.aquaeng.2018.10.004

Wang, X., Frankenberger, J. R., \& Kladivko, E. J. (2003). Estimating nitrate-N losses from subsurface drains using variable water sampling frequencies. Trans. ASAE, 46(4), 10331040. https://doi.org/10.13031/2013.13965

Warneke, S., Schipper, L. A., Bruesewitz, D. A., \& Baisden, W. T. (2011a). A comparison of different approaches for measuring denitrification rates in a nitrate-removing bioreactor. Water Res., 45(14), 4141-4151. https://doi.org/10.1016/j.watres.2011.05.027

Warneke, S., Schipper, L. A., Bruesewitz, D. A., McDonald, I., \& Cameron, S. (2011b). Rates, controls, and potential adverse effects of nitrate removal in a denitrification bed. Ecol. Eng., 37(3), 511-522. https://doi.org/10.1016/j.ecoleng.2010.12.006

Wickramarathne, N. M., Cooke, R. A., Book, R. S., \& Christianson, L. E. (2020). Denitrifying woodchip bioreactor leachate tannic acid and true color: Lab and field studies. Trans. ASABE, 63(6), 1747-1757. https://doi.org/10.13031/trans. 14020

Williams, M. R., King, K. W., Macrae, M. L., Ford, W., Van Esbroeck, C., Brunke, R. I., ... Schiff, S. L. (2015). Uncertainty in nutrient loads from tile-drained landscapes: Effect of sampling frequency, calculation algorithm, and compositing strategy. J. Hydrol., 530, 306-316. https://doi.org/10.1016/j.jhydrol.2015.09.060

Woli, K. P., David, M. B., Cooke, R. A., McIsaac, G. F., \& Mitchell, C. A. (2010). Nitrogen balance in and export from agricultural fields associated with controlled drainage systems and denitrifying bioreactors. Ecol. Eng., 36(11), 1558-1566. https://doi.org/10.1016/j.ecoleng.2010.04.024

Zoski, E. D., Lapen, D. R., Gottschall, N., Murrell, R. S., \& Schuba, B. R. (2013). Nitrogen, phosphorus, and bacteria removal in laboratory-scale woodchip bioreactors amended with drinking water treatment residuals. Trans. ASABE, 56(4), 1339-1347. https://doi.org/10.13031/trans.56.9836 


\section{APPENDIX}

Table A1. Compilation of field studies reported after meta-analysis performed by Addy et al. (2016). Abbreviations and symbols are as follows: $\mathrm{V}=$ bioreactor volume, $\mathrm{HRT}=$ reported hydraulic retention time, $\mathrm{NRE}=\mathrm{N}$ removal efficiency (noted as concentration or load), $\mathrm{NRR}=\mathrm{N}$ removal rate, $\mathrm{WC}=$ woodchips, $\mathrm{WTR}=$ waste treatment plant residuals, $\mathrm{CF}=$ constant pumped flow, $*=$ concentration reduction, $\dagger=$ load reduction, $\$=$ these bioreactors have high dissolved organic carbon (DOC) in the influent likely resulting in higher NRE and NRR, and ** = additional personal communication with the authors.

\begin{tabular}{|c|c|c|c|c|c|c|c|c|c|c|c|}
\hline Source & Location & Type & Installed & $\begin{array}{l}\text { Volume } \\
\left(\mathrm{m}^{3}\right)\end{array}$ & $\begin{array}{c}\text { Area } \\
\text { Treated } \\
\text { (ha) }\end{array}$ & $\begin{array}{c}\text { HRT } \\
(\mathrm{h} \text { or d) }\end{array}$ & $\begin{array}{l}\text { Influent } \\
\text { N Conc. } \\
\left(\mathrm{mg} \mathrm{N} \mathrm{L}^{-1}\right)\end{array}$ & $\begin{array}{c}\mathrm{N} \\
\text { Removal } \\
\text { Efficiency } \\
(\%) \\
\end{array}$ & $\begin{array}{c}\mathrm{N} \\
\text { Removal } \\
\text { Rate } \\
\left(\mathrm{g} \mathrm{N} \mathrm{m}^{-3} \mathrm{~d}^{-1}\right)\end{array}$ & $\begin{array}{l}\text { Reporting } \\
\text { Period }\end{array}$ & Notes \\
\hline $\begin{array}{c}\text { Bock et al., } \\
2018\end{array}$ & $\begin{array}{c}\text { Middlesex } \\
\text { County, VA }\end{array}$ & Bed & $\begin{array}{l}\text { Aug. } \\
2014\end{array}$ & 25.3 & 6.5 & 3 to $20 \mathrm{~h}$ & 3.7 & $9.5 \dagger$ & 0.56 & $\begin{array}{c}\text { Sept. } 2015 \\
\text { to Sept. } 2016\end{array}$ & $\begin{array}{c}90 \% \text { WC } 10 \% \text { biochar } \\
\text { (v:v) }\end{array}$ \\
\hline $\begin{array}{l}\text { Christianson } \\
\text { et al., } 2017 \\
\end{array}$ & $\begin{array}{c}\text { Caroline } \\
\text { County, MD }\end{array}$ & $\begin{array}{c}\text { Stream } \\
\text { bed }\end{array}$ & $\begin{array}{l}\text { Nov. } \\
2015\end{array}$ & 248.9 & 35 & N/A & 3.98 & $\begin{array}{l}75^{*} \\
25^{\dagger} \\
\end{array}$ & 0.97 & $295 \mathrm{~d}$ & $\begin{array}{l}\text { Treated ditch water } \\
\text { from rotating crops }\end{array}$ \\
\hline $\begin{array}{l}\text { Christianson } \\
\text { et al., } 2017 \\
\end{array}$ & $\begin{array}{c}\text { Somerset } \\
\text { County, MD }\end{array}$ & $\begin{array}{c}\text { Stream } \\
\text { bed }\end{array}$ & $\begin{array}{l}\text { Dec. } \\
2015\end{array}$ & $\begin{array}{l}20.8- \\
29.3 \\
\end{array}$ & 6.6 & $\sim 24 \mathrm{~h}$ & 2.53 & $65^{*}$ & N/A & $\begin{array}{l}4 \text { months of } \\
\text { first year }\end{array}$ & $\begin{array}{c}\text { In-ditch bioreactor } \\
\text { built in three segments }\end{array}$ \\
\hline $\begin{array}{l}\text { Christianson } \\
\text { et al., } 2017\end{array}$ & $\begin{array}{c}\text { Somerset } \\
\text { County, MD }\end{array}$ & $\begin{array}{c}\text { Stream } \\
\text { bed }\end{array}$ & $\begin{array}{l}\text { Feb. } \\
2015\end{array}$ & 19.8 & 0.08 & N/A & $\begin{array}{c}5.5 \text { and } \\
4.9\end{array}$ & $>90^{*}$ & $\begin{array}{c}1.9 \& \\
2.9\end{array}$ & $\sim 1$ year & Sawdust wall \\
\hline $\begin{array}{c}\text { Goeller et al., } \\
2019 \\
\end{array}$ & $\begin{array}{l}\text { Canterbury } \\
\text { Plains, NZ }\end{array}$ & bed & $\begin{array}{l}\text { Oct. } \\
2015\end{array}$ & 25.0 & 160 & $0.9 \mathrm{~h}$ & N/A & $10 *$ & 50.9 & $\begin{array}{c}\text { Dec. } 2015 \\
\text { to Oct. } 2017\end{array}$ & $\begin{array}{l}\text { Closed pit, tile drainage } \\
\text { from dairy pasture }+\end{array}$ \\
\hline $\begin{array}{c}\text { Goeller et al., } \\
2019 \\
\end{array}$ & $\begin{array}{l}\text { Canterbury } \\
\text { Plains, NZ } \\
\end{array}$ & Walls & $\begin{array}{l}\text { Oct. } \\
2015 \\
\end{array}$ & $\begin{array}{l}20.0 \\
24.0 \\
\end{array}$ & 160 & $\begin{array}{l}2.7 \mathrm{~h}, \\
5.5 \mathrm{~h} \\
\end{array}$ & N/A & $\begin{array}{l}57^{*}, \\
99 * \\
\end{array}$ & N/A & $\begin{array}{c}\text { Dec. } 2015 \\
\text { to Oct. } 2017 \\
\end{array}$ & $\begin{array}{l}\text { Two sawdust walls, ripar- } \\
\text { ian seep from dairy pasture }\end{array}$ \\
\hline $\begin{array}{l}\text { Gottschall } \\
\text { et al., } 2016\end{array}$ & $\begin{array}{l}\text { Eastern } \\
\text { Ontario, } \\
\text { Canada } \\
\end{array}$ & Bed & $\begin{array}{l}\text { Oct. } \\
2011\end{array}$ & $\begin{array}{l}3.3 \\
3.3 \\
3.3 \\
\end{array}$ & $\begin{array}{l}0.14 \\
0.14 \\
0.14 \\
\end{array}$ & N/A & $\mathrm{N} / \mathrm{A}$ & $\begin{array}{l}39 * \\
62 * \\
63 * \\
\end{array}$ & $\begin{array}{l}6.58 \\
7.80 \\
6.36 \\
\end{array}$ & $\begin{array}{c}\text { Sept. } 2013 \\
\text { to May } 2014\end{array}$ & $\begin{array}{l}\text { Six bioreactors, two repli- } \\
\text { cates WC, WC and } 10 \% \\
\text { WTR, WC and } 20 \% \text { WTR }\end{array}$ \\
\hline $\begin{array}{l}\text { Hassanpour } \\
\text { et al., } 2017\end{array}$ & $\begin{array}{c}\text { Tompkins } \\
\text { County, NY }\end{array}$ & Beds & $\begin{array}{l}\text { Oct. } \\
2012 \\
\end{array}$ & 9.5 & 4 & $\begin{array}{l}2.2 \mathrm{~d} \\
2.1 \mathrm{~d}\end{array}$ & 9.3 & $\begin{array}{l}42 * \\
55^{*}\end{array}$ & $\begin{array}{l}3.8 \\
4.7 \\
\end{array}$ & 2013-2015 & $\begin{array}{c}1 \mathrm{WC} \text { and } 1 \mathrm{WC}+ \\
10 \% \text { biochar, closed pit }\end{array}$ \\
\hline $\begin{array}{l}\text { Hassanpour } \\
\text { et al., } 2017 \\
\end{array}$ & $\begin{array}{l}\text { Chemung } \\
\text { County, NY }\end{array}$ & Beds & $\begin{array}{l}\text { June } \\
2013 \\
\end{array}$ & $\begin{array}{l}9.5 \\
17.1 \\
\end{array}$ & 5 & $\begin{array}{l}0.5 \mathrm{~d} \\
0.3 \mathrm{~d} \\
\end{array}$ & 6.2 & $\begin{array}{l}68^{*}, \\
66^{*} \\
\end{array}$ & $\begin{array}{l}13.5 \\
15.1 \\
\end{array}$ & $2013-2015$ & $\begin{array}{c}1 \mathrm{WC} \text { and } 1 \mathrm{WC}+ \\
10 \% \text { biochar, closed pit }\end{array}$ \\
\hline $\begin{array}{l}\text { Hassanpour } \\
\text { et al., } 2017 \\
\end{array}$ & $\begin{array}{c}\text { Steuben } \\
\text { County, NY } \\
\end{array}$ & Beds & $\begin{array}{l}\text { July } \\
2013 \\
\end{array}$ & $\begin{array}{l}12.1 \\
17.1 \\
\end{array}$ & 6,9 & $\begin{array}{l}2.8 \mathrm{~d} \\
2.3 \mathrm{~d} \\
\end{array}$ & $\begin{array}{l}18.4 \\
16.6 \\
\end{array}$ & $\begin{array}{l}58 * \\
62 * \\
\end{array}$ & $\begin{array}{l}4.7 \\
6.7 \\
\end{array}$ & $2013-2015$ & $\begin{array}{c}1 \mathrm{WC} \text { and } 1 \mathrm{WC}+ \\
2 \% \text { biochar, closed pit }\end{array}$ \\
\hline $\begin{array}{c}\text { Husk et al., } \\
2017\end{array}$ & $\begin{array}{l}\text { South central } \\
\text { Quebec, } \\
\text { Canada }\end{array}$ & Beds & $\begin{array}{l}\text { July } \\
2012\end{array}$ & $\begin{array}{l}33.0 \\
10.1 \\
22.7 \\
33.0\end{array}$ & $\begin{array}{l}0.61 \\
0.69 \\
0.93 \\
1.28 \\
\end{array}$ & $\begin{array}{l}14.1 \mathrm{~h}, \\
5.3 \mathrm{~h} \\
27 \mathrm{~h} \\
14 \mathrm{~h}\end{array}$ & 5.3 & $99 \dagger$ & $\begin{array}{c}6.84 \\
\text { (median) }\end{array}$ & $2012-2015$ & $\begin{array}{c}\text { Four bioreactors monitored } \\
\text { three years for } 12 \text { site- } \\
\text { years of data cumulative. } \\
\text { All closed pit }\end{array}$ \\
\hline $\begin{array}{l}\text { Hoffmann } \\
\text { et al., } 2019\end{array}$ & $\begin{array}{l}\text { Jutland, } \\
\text { Denmark }\end{array}$ & Beds & $\begin{array}{c}\text { Fall } \\
2012\end{array}$ & 100 & 78 & N/A & $\begin{array}{c}14 \\
\text { May }\end{array}$ & $\begin{array}{l}55 \dagger, 56 \dagger \\
43 \dagger, 46 \dagger \\
50 \dagger, 55 \dagger\end{array}$ & $\begin{array}{l}1.67- \\
2.22\end{array}$ & $2013-2014$ & $\begin{array}{l}\text { Six bioreactors with mixed } \\
\text { media (seashells/willow } \\
\text { WC) at 50:50 and } 25: 75 \text {. } \\
\text { Closed pit with vegetation. }\end{array}$ \\
\hline $\begin{array}{l}\text { Pfannerstill } \\
\text { et al., } 2016\end{array}$ & $\begin{array}{c}\text { North } \\
\text { German } \\
\text { lowlands } \\
\end{array}$ & $\begin{array}{c}\text { Stream } \\
\text { bed }\end{array}$ & 2010 & N/A & N/A & N/A & 8.9 & $\begin{array}{l}28^{*} \\
15^{\dagger}\end{array}$ & N/A & $\begin{array}{l}\text { Aug. } 2010 \\
\text { to Apr. } 2012\end{array}$ & $\begin{array}{l}\text { Drainage reactive } \\
\text { ditch with tile from } \\
\text { a farm, } 12 \mathrm{~m}^{3} \mathrm{WC}\end{array}$ \\
\hline $\begin{array}{c}\text { Pluer et al., } \\
2018\end{array}$ & $\begin{array}{l}\text { Sarasota, } \\
\text { FL }\end{array}$ & & $\begin{array}{l}\text { Nov. } \\
2013\end{array}$ & 4.32 & 16.4 & $\mathrm{CF}$ & N/A & N/A & 7.9 & $\begin{array}{l}\text { Nov. } 2013 \\
\text { to Nov. } 2014 \\
\end{array}$ & $\begin{array}{c}\text { Open pit, submerged } \\
\text { bios in retention ponds }\end{array}$ \\
\hline $\begin{array}{c}\text { Pluer et al., } \\
2018\end{array}$ & $\begin{array}{l}\text { Sarasota, } \\
\text { FL }\end{array}$ & & $\begin{array}{l}\text { Oct. } \\
2013\end{array}$ & 4.32 & 22.9 & $\mathrm{CF}$ & N/A & N/A & 3.4 & $\begin{array}{l}\text { Nov. } 2013 \\
\text { to Nov. } 2014\end{array}$ & $\begin{array}{c}\text { Open pit, submerged } \\
\text { bios in retention ponds }\end{array}$ \\
\hline $\begin{array}{c}\text { Rambags } \\
\text { et al., } 2016 \\
\end{array}$ & $\begin{array}{c}\text { Newstead, } \\
\text { NZ } \\
\end{array}$ & Bed & $\begin{array}{l}\text { May } \\
2013 \\
\end{array}$ & 114 & $\mathrm{CF}$ & 7 to $10 \mathrm{~d}$ & $\begin{array}{l}\text { Avg. } \\
31.2 \\
\end{array}$ & $>99 *$ & $\sim 14$ & $\begin{array}{l}\text { Aug. } 2013 \\
\text { to June } 2015 \\
\end{array}$ & $\begin{array}{l}\text { Closed pit trapezoidal, } \\
\text { treating human waste }\end{array}$ \\
\hline $\begin{array}{c}\text { Rosen and } \\
\text { Christianson, } \\
2017\end{array}$ & $\begin{array}{c}\text { Caroline } \\
\text { County, MD }\end{array}$ & Bed & $\begin{array}{l}\text { Nov. } \\
2013\end{array}$ & 169.3 & 34.7 & $>10 \mathrm{~d}$ & $\begin{array}{r}4.7 \\
7.7\end{array}$ & $\begin{array}{l}9 \dagger \\
16 \dagger\end{array}$ & $\begin{array}{l}0.4 \\
0.21\end{array}$ & $\begin{array}{c}\text { Aug. } 2014 \\
\text { to Aug. } 2015 \text {, } \\
\text { Aug. } 2015 \\
\text { to May } 2016 \\
\end{array}$ & $\begin{array}{l}\text { Closed pit treating } \\
\text { dairy farm }\end{array}$ \\
\hline $\begin{array}{c}\text { Rosen and } \\
\text { Christianson, } \\
2017\end{array}$ & $\begin{array}{l}\text { Queen Anne's } \\
\text { County, MD }\end{array}$ & Bed & $\begin{array}{l}\text { Dec. } \\
2013\end{array}$ & 90.9 & 25.2 & $\begin{array}{c}>1 \\
\text { week }\end{array}$ & $\begin{array}{l}9.2 \\
8.6\end{array}$ & $\begin{array}{l}62 \dagger \\
47 \dagger\end{array}$ & $\begin{array}{l}5.36 \\
5.12\end{array}$ & $\begin{array}{l}\text { Aug. } 2014 \\
\text { to Aug. } 2015 \text {, } \\
\text { Aug. } 2015 \\
\text { to Apr. } 2016 \\
\end{array}$ & $\begin{array}{l}\text { Closed pit treating } \\
\text { organic grain farm }\end{array}$ \\
\hline $\begin{array}{c}\text { Rosen and } \\
\text { Christianson, } \\
2017 \\
\end{array}$ & $\begin{array}{c}\text { Caroline } \\
\text { County, MD }\end{array}$ & Bed & $\begin{array}{l}\text { Nov. } \\
2014\end{array}$ & 252.6 & 40.1 & $\begin{array}{c}42 \\
\pm 56 \mathrm{~h}\end{array}$ & 13.5 & $10 \dagger$ & 1.53 & $\begin{array}{c}\text { Dec. } 2014 \\
\text { to July } 2015\end{array}$ & $\begin{array}{c}\text { Closed pit treating } \\
\text { conventional row crops }\end{array}$ \\
\hline $\begin{array}{l}\text { von Ahnen } \\
\text { et al., } 2016 \\
\end{array}$ & $\begin{array}{c}\text { North Jutland, } \\
\text { Denmark }\end{array}$ & Bed & $\begin{array}{l}\text { Oct. } \\
2015 \\
\end{array}$ & 12.5 & $\mathrm{CF}$ & $\begin{array}{c}3.3 \text { to } \\
6.5 \mathrm{~h} * * \\
\end{array}$ & 5.6 & N/A & 7.06 & First $147 \mathrm{~d}$ & $\begin{array}{c}\text { Treating startup rainbow } \\
\text { trout aquaculture } \ddagger\end{array}$ \\
\hline $\begin{array}{l}\text { von Ahnen } \\
\text { et al., } 2018 \\
\end{array}$ & Denmark & Bed & $\begin{array}{c}\text { March } \\
2017 \\
\end{array}$ & 300 & $\mathrm{CF}$ & $17.7 \mathrm{~h}^{* *}$ & 5.3 & $80^{*}$ & 4.8 & $\begin{array}{l}52 \text { weeks } \\
\text { from install }\end{array}$ & $\begin{array}{c}\text { Horizontal flow, rainbow } \\
\text { trout aquaculture }+\end{array}$ \\
\hline $\begin{array}{l}\text { von Ahnen } \\
\text { et al., } 2018\end{array}$ & Denmark & Bed & $\begin{array}{l}\text { July } \\
2017\end{array}$ & 660 & $\mathrm{CF}$ & $11.0 \mathrm{~h}^{* *}$ & 10.5 & $29 *$ & 4.5 & $\begin{array}{c}28 \text { weeks } \\
\text { start } 6 \text { weeks } \\
\text { after install }\end{array}$ & $\begin{array}{c}\text { Vertical/downflow, } \\
\text { rainbow trout } \\
\text { aquaculture }\end{array}$ \\
\hline $\begin{array}{l}\text { von Ahnen } \\
\text { et al., } 2018\end{array}$ & Denmark & Bed & $\begin{array}{l}\text { Jan. } \\
2017\end{array}$ & 1440 & $\mathrm{CF}$ & $10.4 \mathrm{~h} * *$ & 9.5 & $48^{*}$ & 7.8 & $\begin{array}{c}52 \text { weeks } \\
\text { start } 7 \text { weeks } \\
\text { after install }\end{array}$ & $\begin{array}{c}\text { Vertical/downflow, } \\
\text { rainbow trout } \\
\text { aquaculture: }\end{array}$ \\
\hline
\end{tabular}


Personnel: $\quad$ Laura Christianson with help from Ronnie Chacon

Weather and site conditions: Party cloudy, hot (high of $85 \mathrm{~F}$ ), standing water in some access road ruts (state if anything is surprising or unusual)

Recent relevant weather: Rained yesterday (state the amount if known)

Bioreactor observations:

Bioreactor is getting a little weedy; no sulfide smell present near either structure;

\begin{tabular}{|c|c|c|}
\hline \\
\hline \multicolumn{3}{|l|}{ Stop log measurement and management } \\
\hline Number of plates when arriving on-site & 4 & 3 \\
\hline Plate heights & $7^{\prime \prime}+7^{\prime \prime}+7^{\prime \prime}+V$ plate & $5^{\prime \prime}+5^{\prime \prime}+V$ plate \\
\hline Were the plates changed today? & No & No \\
\hline New number of plates & none & none \\
\hline New plate height & none & none \\
\hline Was flow observed over the stop logs? & No & Yes \\
\hline Manual water depth recorded & Kolor Kut value of $207 / 8$ ths inches & Kolor Kut value of $161 / 4$ ths inches \\
\hline Additional notes & $V$-notch plate present & Slime observed; $V$-notch plate present \\
\hline
\end{tabular}

Sample collection:

\begin{tabular}{|c|c|c|}
\hline collection: & Inflow Structure & Outflow Structure \\
\hline Manual grab sample & (number of samples; notes) & (number of samples; notes) \\
\hline Auto-sampled & (number of samples; notes) & (number of samples; notes) \\
\hline Samples from on-site personnel & (number of samples; notes) & (number of samples; notes) \\
\hline
\end{tabular}

Sampling notes: The outflow autosampler malfunctioned for the outflow samples from day 09-14 June;

only partial samples were collected; The inflow sampler was flooded, all samples lost.

\section{Flow data:}

Pressure transducer downloaded

Barometric pressure transducer:

Flow notes:

bringing the old one back to the lab for testing

\begin{tabular}{|c|c}
\hline Inflow Structure & Outflow Structure \\
\hline (file name or notes) & (file name or notes) \\
\hline
\end{tabular}

(file name or notes)

the inflow structure (which flooded);

Additional testing notes: We can likely start a tracer test here soon (bypass flow has ceased);

Did not collect well samples this time; need to do this next week

Future action items: $\quad$ Replaced inflow pressure transducer; need to replace one of the spare ones in the work truck.

Saw Farmer John on-site, he reminded me about the upcoming field day on June 28

Bring weedeater next time

Figure A1. Field log sheet with example entries for personnel collecting data at denitrifying bioreactors treating subsurface drainage. 